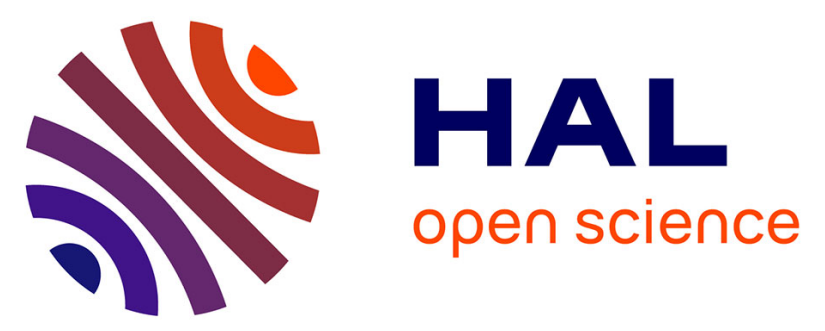

\title{
Synthesis, photophysics and molecular structures of luminescent 2,5-bis(phenylethynyl)thiophenes (BPETs)
}

Jamie S. Siddle, Richard M. Ward, Jonathan C. Collings, Simon R. Rutter, Laurent Porrès, Lucas Applegarth, Andrew Beeby, Andrei S. Batsanov, Amber L. Thompson, Judith A. K. Howard, et al.

\section{To cite this version:}

Jamie S. Siddle, Richard M. Ward, Jonathan C. Collings, Simon R. Rutter, Laurent Porrès, et al.. Synthesis, photophysics and molecular structures of luminescent 2,5-bis(phenylethynyl)thiophenes (BPETs). New Journal of Chemistry, 2007, 31 (6), pp.841-851. 10.1039/B701172E . hal-00862434

\section{HAL Id: hal-00862434 https://hal.science/hal-00862434}

Submitted on 16 Sep 2013

HAL is a multi-disciplinary open access archive for the deposit and dissemination of scientific research documents, whether they are published or not. The documents may come from teaching and research institutions in France or abroad, or from public or private research centers.
L'archive ouverte pluridisciplinaire HAL, est destinée au dépôt et à la diffusion de documents scientifiques de niveau recherche, publiés ou non, émanant des établissements d'enseignement et de recherche français ou étrangers, des laboratoires publics ou privés. 


\title{
Synthesis, photophysics and molecular structures of luminescent 2,5-bis(phenylethynyl)thiophenes (BPETs)
}

\author{
Jamie S. Siddle, ${ }^{a}$ Richard M. Ward,${ }^{a}$ Jonathan C. Collings, ${ }^{a}$ Simon R. Rutter, ${ }^{a}$ \\ Laurent Porrès, ${ }^{a}$ Lucas Applegarth, ${ }^{a}$ Andrew Beeby, ${ }^{a}$ Andrei S. Batsanov, ${ }^{a}$ \\ Amber L. Thompson, ${ }^{a}$ Judith A. K. Howard, ${ }^{a}$ Abdou Boucekkine, ${ }^{b}$ Karine Costuas, ${ }^{b}$ \\ Jean-François Halet ${ }^{b}$ and Todd B. Marder ${ }^{*} a$
}

Received (in Montpellier, France) 25th January 2007, Accepted 21st March 2007

First published as an Advance Article on the web 12th April 2007

DOI: $10.1039 / b 701172 \mathrm{e}$

\begin{abstract}
The Sonogashira cross-coupling of two equivalents of para-substituted ethynylbenzenes with 2,5-diiodothiophene provides a simple synthetic route for the preparation of 2,5-bis(para-Rphenylethynyl)thiophenes ( $\mathrm{R}=\mathrm{H}, \mathrm{Me}, \mathrm{OMe}, \mathrm{CF}_{3}, \mathrm{NMe}_{2}, \mathrm{NO}_{2}, \mathrm{CN}$ and $\left.\mathrm{CO}_{2} \mathrm{Me}\right)(\mathbf{1 a}-\mathbf{h})$. Likewise, 2,5-bis(pentafluorophenylethynyl)thiophene (2) was prepared by the coupling of 2,5diiodothiophene with pentafluorophenylacetylene. All compounds were characterised by NMR, IR, Raman and mass spectroscopy, elemental analysis, and their absorption and emission spectra, quantum yields and lifetimes were also measured. The spectroscopic studies of $\mathbf{1 a}-\mathbf{h}$ and $\mathbf{2}$ show that both electron donating and electron withdrawing para-subsituents on the phenyl rings shift the absorption and emission maxima to lower energies, but that acceptors are more efficient in this regard. The short singlet lifetimes and modest fluorescence quantum yields (ca. 0.2-0.3) observed are characteristic of rapid intersystem crossing. The single-crystal structures of 2,5bis(phenylethynyl)thiophene, 2,5-bis(para-carbomethoxyphenylethynyl)thiophene, 2,5-bis(paramethylphenylethynyl)thiophene and 2,5-bis(pentafluorophenylethynyl)thiophene were determined by X-ray diffraction at $120 \mathrm{~K}$. DFT calculations show that the all-planar form of the compounds is the lowest in energy, although rotation of the phenyl groups about the $\mathrm{C} \equiv \mathrm{C}$ bond is facile and TD-DFT calculations suggest that, similar to 1,4-bis(phenylethynyl)benzene analogues, the absorption spectra in solution arise from a variety of rotational conformations. Frequency calculations confirm the assignments of the compounds' IR and Raman spectra.
\end{abstract}

\section{Introduction}

Conjugated systems, such as 1,4-bis(phenylethynyl)benzenes (BPEBs) ${ }^{1-15}$ and 9,10-bis(phenylethynyl)anthracenes (BPEAs), ${ }^{16-18}$ show interesting structural, electronic and luminescent properties, and have been well studied; however, there are far fewer examples of 2,5-bis(phenylethynyl)thiophenes (BPETs). The few BPETs that have been reported are of interest due to their luminescence ${ }^{19-24}$ and non-linear optical $^{25-27}$ properties, as well as their liquid crystalline phase behaviour, which they owe to the bent nature of the thiophene moiety. ${ }^{28-31}$ An optically active (axially chiral) bis-BPET derivative has been described, ${ }^{32}$ as well as transition metal $\pi$-complexes containing BPETs as ligands. ${ }^{33 a}$ Closely related to the BPETs are 2,5-bis(pyridylethynyl)thiophenes, ${ }^{33 b-d}$ which have the capacity to coordinate to transition metal atoms (via nitrogen), and thus can be used to create photoconducting solids or molecular wires.

There are a number of routes for the synthesis of BPETs. The most straightforward methods utilise the catalytic cross-

\footnotetext{
${ }^{a}$ Department of Chemistry, Durham University, South Road, Durham, UKDH13LE.E-mail: todd.marder@durham.ac.uk; Fax: + 44 191384-4737; Tel: + 44 191-334-2037

${ }^{b}$ UMR CNRS 6226 Sciences Chimiques de Rennes, Université de Rennes 1, Campus de Beaulieu, 35042 Rennes, France
}

coupling of terminal alkynes ${ }^{19-23}$ or alkynyl Grignard reagents $^{34}$ with 2,5-halothiophenes, giving BPETs in good yields. Pd-catalysed cross-coupling has also been used to produce BPETs in good yields from triorganoindium compounds and 2,5-dibromothiophene. ${ }^{35}$ Other methods include longer reaction sequences involving elimination reactions. A one-pot synthesis using benzyl sulfone derivatives and 2-formyl-5-phenylethynylthiophene, incorporating two sequential eliminations from the reaction intermediates, has been developed, forming symmetrical or unsymmetrical BPETs in good yields. ${ }^{36}$ The compound 1,8-diphenyl-1,7-octadiyne-3,6-dione, synthesised in nine steps from 1,4-butanediol, can also be converted to a BPET by a reaction with bis(triphenyl)tin sulfide in the presence of $\mathrm{BCl}_{3}{ }^{37}$

To complement our current work on luminescent mer,cis[tris(trimethylphosphine)-trimethylsilylethynyl-2,5-bis(para-Rphenylethynyl)-3,4-(para-R-phenyl)rhodacyclopenta-2,4-dienes], ${ }^{38}$ we have synthesised a number of structurally related 2,5-bis(para-R-phenylethynyl)thiophenes with the aim of evaluating the role of the heteroatom on the optical properties of heterocyclopentadienes. Herein, we report the synthesis and optical properties of 2,5-bis(para-R-phenylethynyl)thiophenes, $\mathrm{R}=\mathrm{H}(\mathbf{1 a}), \mathrm{Me}(\mathbf{1 b}), \mathrm{OMe}(\mathbf{1 c}), \mathrm{CF}_{3}$ (1d), $\mathrm{NMe}_{2}$ (1e), $\mathrm{NO}_{2}$ (1f), $\mathrm{CN}$ (1g) and $\mathrm{CO}_{2} \mathrm{Me}(\mathbf{1 h}), 2,5$-bis(pentafluorophenylethynyl)-thiophene (2) and the crystal and molecular 

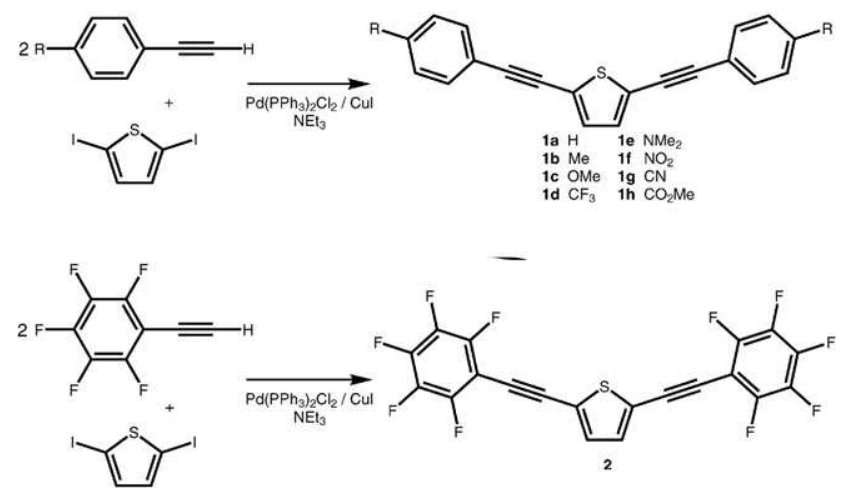

Scheme 1

structures of selected examples. A more detailed study of the photophysical behaviour of the parent compound 1a is given in a companion paper. ${ }^{39}$

\section{Results and discussion}

\section{Syntheses}

Compounds $\mathbf{1 a}-\mathbf{h}$ and $\mathbf{2}$ were synthesised via the Sonogashira cross-coupling reaction of 2,5-diiodothiophene with two equivalents of the appropriate substituted ethynylbenzene at room temperature for 24-96 h, except for $\mathbf{1 h}$, which was stirred at room temperature for $24 \mathrm{~h}$ and then heated to $80{ }^{\circ} \mathrm{C}$ for $2 \mathrm{~h}$, catalysed by $2 \mathrm{~mol} \% \mathrm{Pd}\left(\mathrm{PPh}_{3}\right)_{2} \mathrm{Cl}_{2}$ and $\mathrm{CuI}$ in triethylamine or diethylamine, ${ }^{40}$ as shown in Scheme 1. Reactions were monitored by GC-MS or TLC, and the compounds were isolated after passage through a short silica gel column eluting with hexane, hexane $/ \mathrm{CH}_{2} \mathrm{Cl}_{2}$ or hot toluene. Compounds $\mathbf{1 a},{ }^{22,34-37} \mathbf{1} \mathbf{c}^{33,41}$ and $\mathbf{1} \mathbf{e}^{19,20}$ have previously been reported, although no synthetic or characterisation details were given for 1c. Analogues of 1c, containing longer alkoxy substituents, have been reported very recently, along with their liquid crystal phase behaviour and optical properties. ${ }^{30 b}$ Compound 1e is reported to have been synthesized in almost quantitative yield; however, the procedure, surprisingly, used a $1: 1$ ratio of 4- $N, N$-dimethylaminophenylacetylene to 2,5-diiodothiophene with $10 \mathrm{~mol} \%$ of a $\operatorname{Pd}($ II) catalyst precursor, which should: (a) generate no more than $50 \%$ yield based on 2,5-diiodothiophene, and (b) generate a significant amount $(10 \%)$ of the 4$\mathrm{Me}_{2} \mathrm{~N}-\mathrm{C}_{6} \mathrm{H}_{4}-\mathrm{C} \equiv \mathrm{C}-\mathrm{C} \equiv \mathrm{C}-\mathrm{C}_{6} \mathrm{H}_{4}-4-\mathrm{NMe}_{2}$ diyne, further consuming $20 \%$ of the starting alkyne during the catalyst activation step. ${ }^{1,42}$ Both of these factors should significantly reduce the overall yield of 1 e obtained. We have prepared compound 1e in moderate yield using $2 \mathrm{~mol} \% \mathrm{Pd}$ catalyst and did not observe a significant amount of diyne formation (i.e. beyond that required for catalyst precursor reduction). We also note that analytically pure samples of several of the compounds showed melting ranges that were slightly broader than expected, possibly an indication of transient liquid crystal phase behaviour, ${ }^{30 b}$ but this aspect was not investigated further.

\section{Optical properties}

The optical properties (absorption and fluorescence maxima, fluorescence quantum yields and lifetimes) for compounds $\mathbf{1} \mathbf{a}-\mathbf{h}$ and $\mathbf{2}$ are presented in Table 1. All compounds show an intense absorption band in the UV region (Fig. 1 and Fig. 2). With the exception of the nitro derivative, 1f, these chromophores are also fluorescent in the UV-vis region with moderate quantum yields of $0.19-0.33$ (Fig. 3 and Fig. 4). It is apparent that the presence of both electron donating and electron withdrawing groups at the para-position of the phenyl rings shifts the absorption as well as the emission maxima bathochromically from $350 \mathrm{~nm}$ for 1a to 386 and $387 \mathrm{~nm}$ for 1e and 1f, respectively, in absorption, and from $382 \mathrm{~nm}$ for $\mathbf{1 a}$ to 434 and $402 \mathbf{n m}$ for $\mathbf{1 e}$ and $\mathbf{1 h}$, respectively, in emission. Compound $\mathbf{1 f}$ is very weakly emissive in toluene, resulting from the presence of the $\mathrm{NO}_{2}$ groups, which lead to nonradiative deactivation of the excited state, meaning its quantum yield could not be determined accurately. This presumably results from the fact that the $\pi \rightarrow \pi^{*}$ transition is higher in energy than the nitro $\mathrm{n} \rightarrow \pi^{*}$ transition, as is often the case for such compounds. However, a quantum yield of 0.17 was measured in the more polar $\mathrm{CH}_{2} \mathrm{Cl}_{2}$ solvent. The excited state lifetimes of these compounds are short compared to those of related BPEA and BPEB systems, ${ }^{3 b, 15 a, b, 16 a}$ and this is mirrored in the lower quantum yields. This observation can be attributed to the excited singlet state, $S_{1}$, undergoing more

Table 1 Spectroscopic data for compounds $\mathbf{1 a - h}$ and $\mathbf{2}$ in toluene, unless otherwise noted.

\begin{tabular}{|c|c|c|c|c|c|c|c|c|c|c|}
\hline Compound & $\mathrm{R}$ & $\begin{array}{c}\lambda_{\max } \\
\mathrm{abs} / \mathrm{nm}\end{array}$ & $\begin{array}{l}\varepsilon / \mathrm{mol}^{-1} \\
\mathrm{~cm}^{-1} \mathrm{dm}^{3}\end{array}$ & $f_{\text {calc }^{a}}$ & $\begin{array}{c}\lambda_{\max } \\
\mathrm{em} / \mathrm{nm}\end{array}$ & $\begin{array}{c}\text { Observed } \mathrm{S}_{1}-\mathrm{S}_{0} \\
\text { energy } / \mathrm{cm}^{-1 b}\end{array}$ & $\begin{array}{c}\text { Calculated } \mathrm{S}_{1}-\mathrm{S}_{0} \\
\text { energy } / \mathrm{cm}^{-1 a}\end{array}$ & $\Phi$ & $\begin{array}{c}\text { Stokes } \\
\text { shift } / \mathrm{cm}^{-1}\end{array}$ & $\begin{array}{l}\text { Lifetime } \\
\tau / \mathrm{ps}\end{array}$ \\
\hline 1a & $\mathrm{H}$ & 350 & 33000 & 1.56 & 382 & 26200 & 25600 & 0.20 & 2400 & 240 \\
\hline 1b & $\mathrm{Me}$ & 353 & 40000 & 1.72 & 386 & 25900 & 25200 & 0.23 & 2400 & 240 \\
\hline $1 \mathrm{c}$ & $\mathrm{OMe}$ & $\begin{array}{l}345 \\
359\end{array}$ & $\begin{array}{l}39000 \\
40000\end{array}$ & 1.76 & 394 & 25400 & 24800 & 0.22 & 2500 & 270 \\
\hline 1d & $\mathrm{CF}_{3}$ & 354 & 40000 & 1.72 & 387 & 25800 & 25000 & 0.22 & 2400 & 230 \\
\hline 1e & $\mathrm{NMe}_{2}$ & 386 & 52000 & 1.99 & 434 & 23000 & 23300 & 0.33 & 2900 & 400 \\
\hline 1f & $\mathrm{NO}_{2}$ & $\begin{array}{r}387 \\
394^{c}\end{array}$ & $\begin{array}{l}44000 \\
42000\end{array}$ & 1.69 & $\begin{array}{l}435 \\
547^{c}\end{array}$ & 23500 & 22100 & $\overline{0.17^{c}}$ & $\begin{array}{l}2900 \\
7100^{c}\end{array}$ & $\overline{930^{c}}$ \\
\hline $1 \mathrm{~g}$ & $\mathrm{CN}$ & 365 & 49000 & 1.93 & 401 & 24900 & 23800 & 0.31 & 2500 & 320 \\
\hline $1 \mathrm{~h}$ & $\mathrm{CO}_{2} \mathrm{Me}$ & 365 & 48000 & 1.89 & 402 & 24900 & 23700 & 0.29 & 2500 & 310 \\
\hline 2 & $\mathrm{~F}^{d}$ & 351 & 39000 & 1.60 & 383 & 26100 & 25300 & 0.19 & 2400 & 210 \\
\hline
\end{tabular}




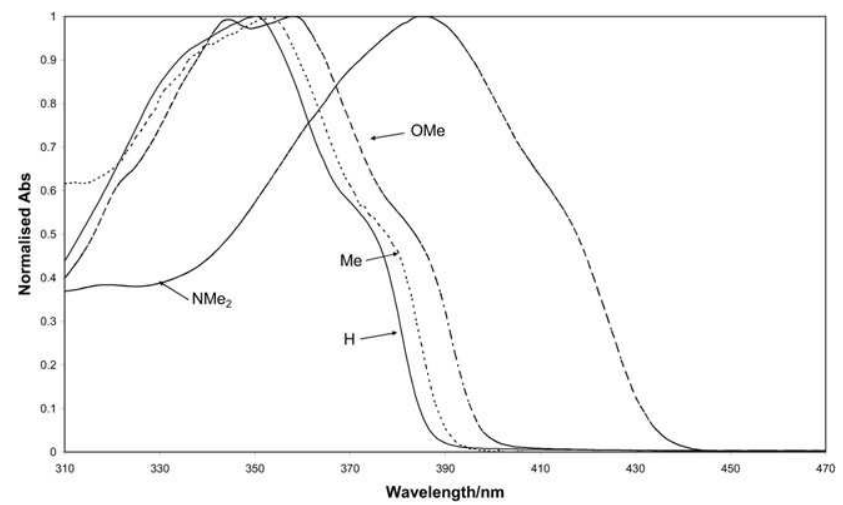

Fig. 1 Absorption spectra of compounds $\mathbf{1 a}-\mathbf{c}$ and $\mathbf{1 e}$.

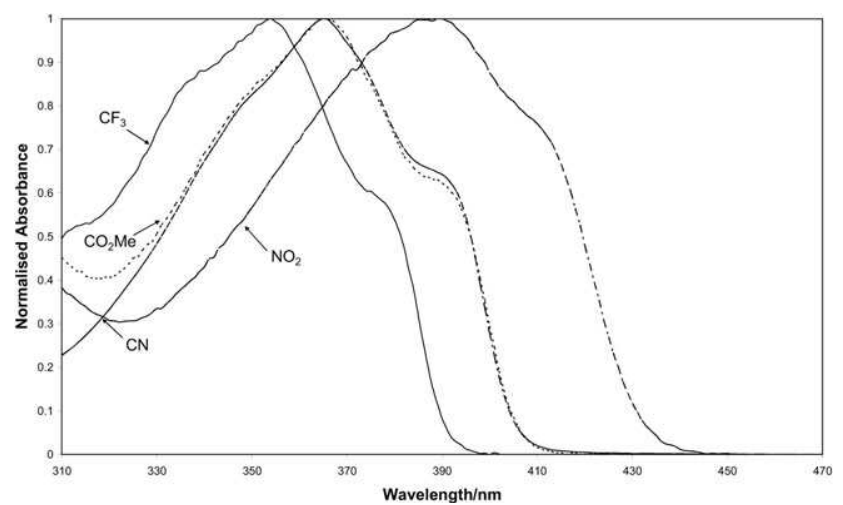

Fig. 2 Absorption spectra of compounds $\mathbf{1 d}$ and $\mathbf{1 f}-\mathbf{h}$.

rapid intersystem crossing (ISC) to the triplet state, $\mathrm{T}_{1}$, for the BPETs compared to their BPEB and BPEA analogues. ${ }^{39}$ ISC is faster due to the introduction of the sulfur, a moderately heavy atom which enhances spin-orbit coupling in the molecule.

A plot of the absorbance maxima against the Hammett constant $^{43}$ for the para-substituent $\left(\sigma_{\mathrm{p}}\right)$, shown in Fig. 5, displays a similar trend to those that we have observed for the analogous BPEBs ${ }^{1}$ and BPEAs. ${ }^{16}$ The absorption maxima for the BPETs are intermediate between the values for BPEBs and BPEAs, with the BPEAs being the most red-shifted of these series. The graph shows a shift of absorbance maxima to lower energy with both stronger electron withdrawing and electron donating para-substituents on the phenyl ring, signifying a reduced energy gap between the $S_{0}$ ground state and $\mathrm{S}_{1}$ excited state in each case. This is the result of the fact that electron donors raise the HOMO more than the LUMO while electron acceptors lower the LUMO more than the HOMO (vide infra). However, in each of the series, the effect of acceptor substituents is greater than that of donor substituents, as can be seen from the gradients of each plot. The difference in gradient between the acceptor series and the donor series increases from BPEBs to BPETs to BPEAs, demonstrating that the photophysical properties for these related compounds, as well as being influenced by the parasubstituents, are also dependent on the nature of the central core. Finally, we note that the optical data for the $\mathrm{MeO}$ derivative, 1c, reported herein is, as expected, essentially

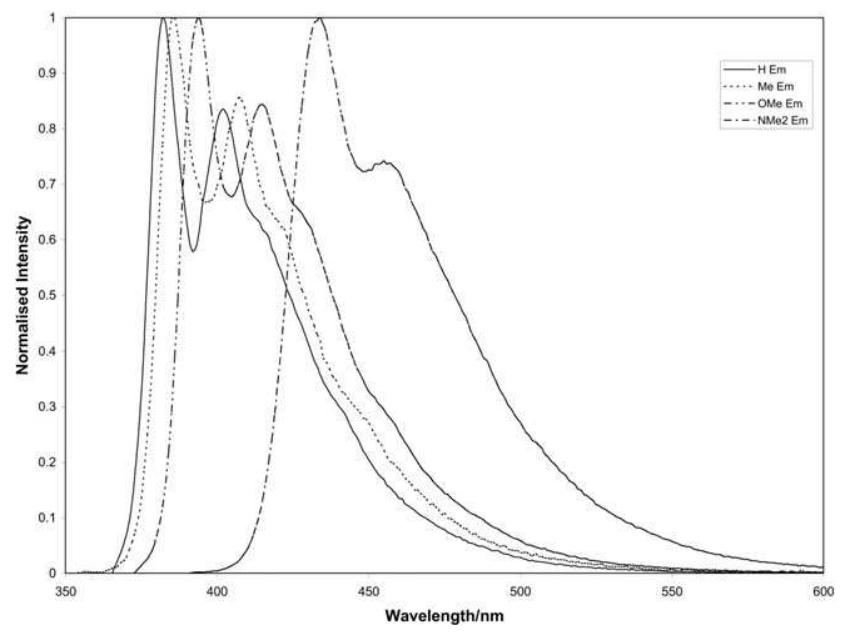

Fig. 3 Emission spectra of compounds 1a-c and 1e.

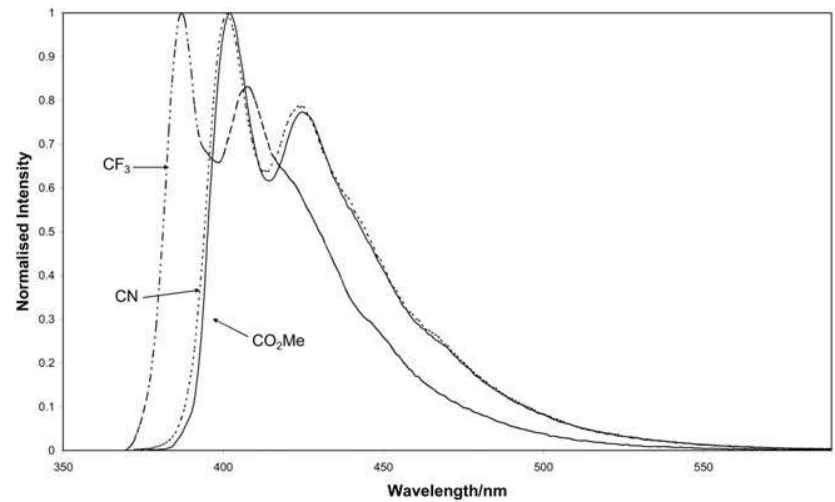

Fig. 4 Emission spectra of compounds 1d, $\mathbf{1 f}$ and $\mathbf{1 h}$.

identical to that reported very recently for the EtO derivative, ${ }^{30 b}$ confirming the accuracy of our data.

\section{Crystal structures}

The structures of $\mathbf{1 a}, \mathbf{1 b}, \mathbf{1 h}$ and $\mathbf{2}$ each contain one independent molecule (Fig. 6) possessing neither crystallographic symmetry nor local symmetry, except for $\mathbf{1 b}$, which has an approximate $C_{2}$ axis. Selected geometric parameters are listed in Table 2. The geometry of the planar thiophene ring is very similar in all four structures, but differs significantly from that of unsubstituted thiophene. The latter proved undeterminable in the solid state due to rotational disorder, complicated polymorphism and an incommensurate structure, ${ }^{44}$ but was recently established (with much difficulty) in the gas phase by a combination of electron diffraction, NMR, rotational and microwave spectroscopy, and $a b$ initio and DFT calculations, ${ }^{45}$ giving equilibrium $\left(r_{\mathrm{e}}\right)$ bond lengths $\mathrm{C}-\mathrm{S}$ 1.704(2), $\mathrm{C}=\mathrm{C} 1.372(3)$ and $\mathrm{C}-\mathrm{C} 1.421(4) \AA$. Longer $\mathrm{C}-\mathrm{S}$ bonds in 1 and 2 probably indicate increased conjugation with the $\mathrm{C} \equiv \mathrm{C}$ bonds. Indeed, the intervening $\mathrm{C}(2)-\mathrm{C}(6)$ and $\mathrm{C}(5)-\mathrm{C}(8)$ bonds are marginally shorter than the corresponding $\mathrm{C}_{\mathrm{sp}}-\mathrm{C}_{\mathrm{sp}^{2}}$ bonds in $\operatorname{tolan}^{46}$ (mean 1.433(3) $\AA$ ) or 1,4-bis(phenylethynyl)benze$n \mathrm{e}^{4 b, 12}$ (mean 1.430(3) $\AA$ ). Comparison of the $\mathrm{C} \equiv \mathrm{C}$ bond lengths is inconclusive, as these distances are not very sensitive 


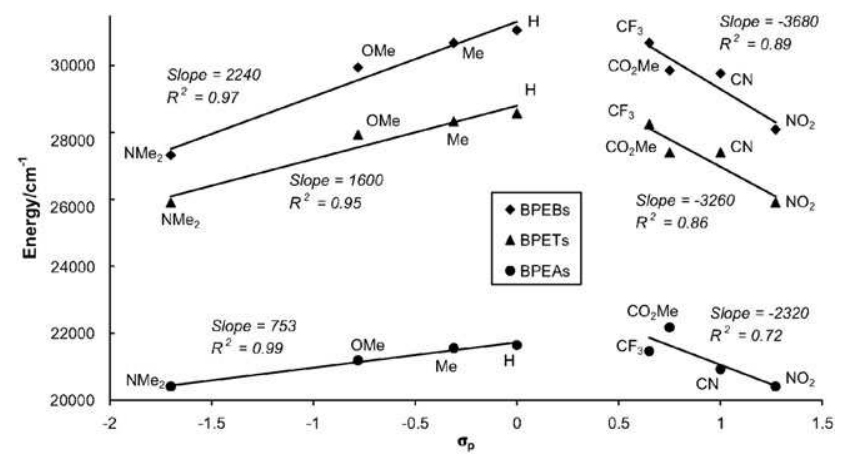

Fig. 5 Plots of absorption maxima $v$. Hammett Constant $\left(\sigma_{\mathrm{p}+} / \sigma_{\mathrm{p}-}\right)$ for the BPETs, 1a-h, and the analogous 1,4-bis(para-R-phenylethynyl)benzenes (BPEBs) and 9,10-bis(para-R-phenylethynyl)anthracenes (BPEAs).

to changes in electronic structure, whilst being rather sensitive to the experimental procedure used to determine them, such as the availability of high-angle reflections. ${ }^{46 a}$ DFT calculations (see Table 2) predict much stronger conjugation.

Molecules $\mathbf{1 b}$ and $\mathbf{1 h}$ are nearly planar, as found for the DFT optimised geometries, vide infra; the carboxylate groups in $\mathbf{1 h}$ have a mutually anti-orientation and are nearly coplanar with the adjacent benzene rings, ii and iii, the dihedral angles being 3.3 and $5.7^{\circ}$, respectively (Fig. 7).

The central thiophene ring inevitably makes the molecular rod non-linear. Indeed, the exocyclic bonds $\mathrm{C}(2)-\mathrm{C}(6)$ and $\mathrm{C}(5)-\mathrm{C}(8)$ are not continuations of the bisector lines of the angles $\mathrm{S}(1)-\mathrm{C}(2)-\mathrm{C}(3)$ and $\mathrm{S}(1)-\mathrm{C}(5)-\mathrm{C}(4)$, but deviate from the latter towards the sulfur atom by several degrees. Thus, the

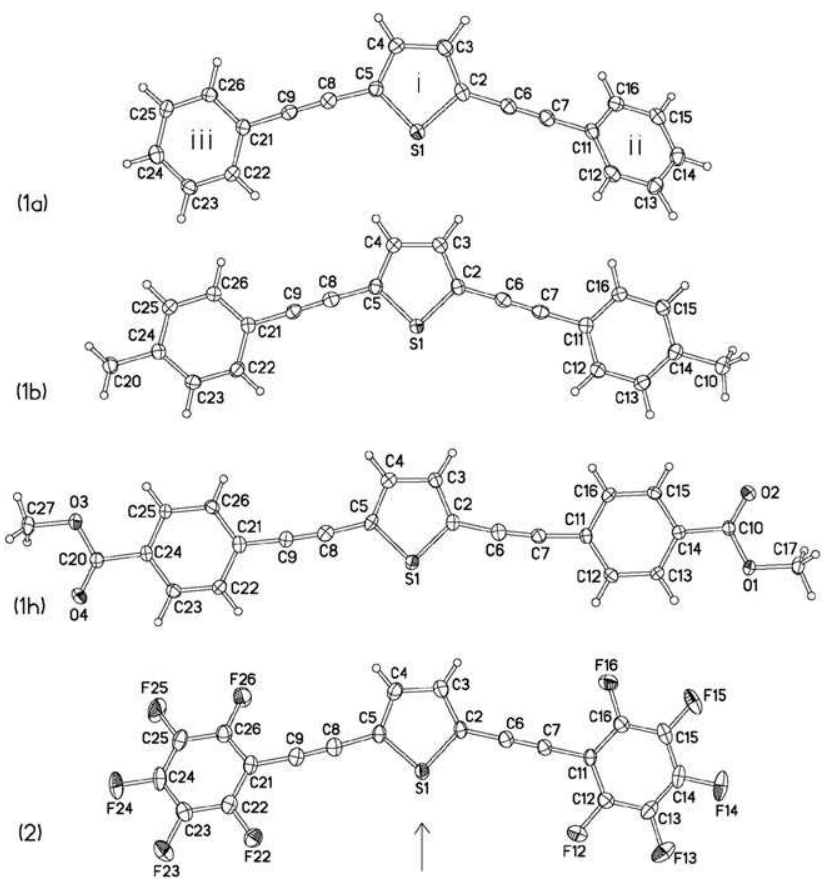

Fig. 6 Molecular structures of $\mathbf{1 a}, \mathbf{1 b}, \mathbf{1 h}$ and $\mathbf{2}(50 \%$ thermal ellipsoids). The arrow indicates the approximate 2-fold axis (see Fig. 7).
Table 2 Mean bond distances $(\AA)$ and angles $\left({ }^{\circ}\right)$ between ring planes ${ }^{a}$ and/or vectors. Calculated distances (DFT, B3LYP, 6-31G*) are italicised

\begin{tabular}{lclll}
\hline & $\mathbf{1 a}$ & $\mathbf{1 b}$ & \multicolumn{1}{c}{$\mathbf{1 h}$} & \multicolumn{1}{c}{$\mathbf{2}$} \\
\hline $\mathrm{C}-\mathrm{S}$ & $1.733(3)$ & $1.727(2)$ & $1.729(2)$ & $1.723(2)$ \\
& 1.758 & 1.758 & 1.757 & 1.758 \\
$\mathrm{C}=\mathrm{C}$ & $1.380(4)$ & $1.378(2)$ & $1.380(3)$ & $1.374(3)$ \\
& 1.386 & 1.386 & 1.387 & 1.387 \\
$\mathrm{C}(3)-\mathrm{C}(4)$ & $1.410(4)$ & $1.405(2)$ & $1.402(3)$ & $1.401(3)$ \\
& 1.411 & 1.411 & 1.409 & 1.409 \\
$\mathrm{C}(2,5)-\mathrm{C} \equiv$ & $1.422(3)$ & $1.422(2)$ & $1.418(3)$ & $1.418(3)$ \\
$\mathrm{C} \equiv \mathrm{C}$ & 1.403 & 1.403 & 1.402 & 1.402 \\
& $1.204(4)$ & $1.183(2)$ & $1.207(3)$ & $1.192(3)$ \\
$\equiv \mathrm{C}-\mathrm{C}(\mathrm{Ph})$ & 1.219 & 1.219 & 1.219 & 1.217 \\
& $1.443(3)$ & $1.444(2)$ & $1.426(3)$ & $1.425(3)$ \\
$\mathrm{i} /$ ii & 1.422 & 1.422 & 1.420 & 1.404 \\
$\mathrm{i} /$ iii & 33.6 & 5.8 & 2.8 & 4.5 \\
$\mathrm{ii} /$ iii & 9.7 & 5.7 & 3.4 & 23.5 \\
$\mathrm{C}(6) \equiv \mathrm{C}(7) / \mathrm{ii}$ & 39.2 & 10.2 & 3.4 & 21.9 \\
$\mathrm{C}(8) \equiv \mathrm{C}(9) / \mathrm{iii}$ & 9.1 & 0.9 & 6.6 & 0.7 \\
$\mathrm{C}(2)-\mathrm{C}(6) / \mathrm{C}(5)-\mathrm{C}(8)$ & $148.6(2)$ & $147.9(2)$ & $153.9(3)$ & $151.6(3)$ \\
$\mathrm{C}(11)-\mathrm{C}(14) / \mathrm{C}(21)-\mathrm{C}(24)$ & $141.1(2)$ & $147.0(2)$ & $175.5(2)$ & $158.7(2)$
\end{tabular}

${ }^{a}$ For the definition of planes i-iii, see Fig. 6.

angles between the $\mathrm{C}(2)-\mathrm{C}(6)$ and $\mathrm{C}(5)-\mathrm{C}(8)$ bonds $\left(148-154^{\circ}\right.$, see Table 2) are considerably smaller than between the bisector lines $\left(\mathrm{ca} .157^{\circ}\right)$ mentioned above. Note that this effect is also observed in unsubstituted thiophene, where the $\mathrm{S}(1)-\mathrm{C}(2)-\mathrm{H}$ and $\mathrm{C}(3)-\mathrm{C}(2)-\mathrm{H}$ angles are very different (119.9(3) and $\left.128.5(3)^{\circ}\right)$ and the $\mathrm{C}(2)-\mathrm{H}$ and $\mathrm{C}(5)-\mathrm{H}$ bonds form an angle of $147.4(3)^{\circ}$.

In $\mathbf{1 b}$, the acetylenic $(-\mathrm{C} \equiv \mathrm{C}-$ ) moieties are practically linear, whereas in $\mathbf{1 h}$ they are substantially bent, which results, paradoxically, in the overall straightening of the molecule, making the $\mathrm{C}(11) \cdots \mathrm{C}(14)$ and $\mathrm{C}(21) \cdots \mathrm{C}(24)$ vectors more co-linear (Table 2). In 1a, the acetylenic groups are bent to a similar extent but, in contrast with $\mathbf{1 h}$, out of the thiophene plane, so that no overall straightening occurs. In $\mathbf{1 a}$ and $\mathbf{2}$, the phenyl rings adopt considerably unsymmetrical orientations.

The crystal packing motif of $\mathbf{1 b}$ is a longitudinally-slanted infinite stack, in which the adjacent molecules are related by the $b$ translation, with a mean interplanar separation of $d=$ $3.57 \AA$. The so-called 'aromatic slip angle', $\theta$, between the translation and the normal to the molecular plane, equals $45.5^{\circ}$, so that the $\mathrm{C} \equiv \mathrm{C}$ bonds of one molecule overlap with

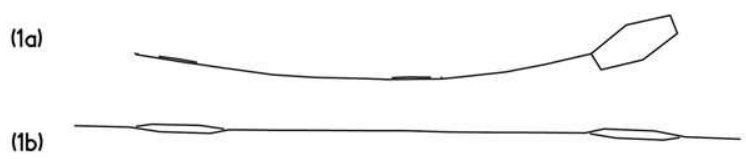

(1h)

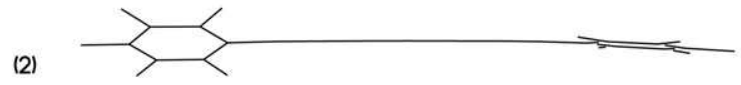

Fig. 7 Molecular structures of $\mathbf{1 a}, \mathbf{1 b}, \mathbf{1 h}$ and $\mathbf{2}$ viewed down the approximately 2 -fold axis of the thiophene ring ( $\rightarrow$ in Fig. 6). Hydrogen atoms are omitted for clarity. 


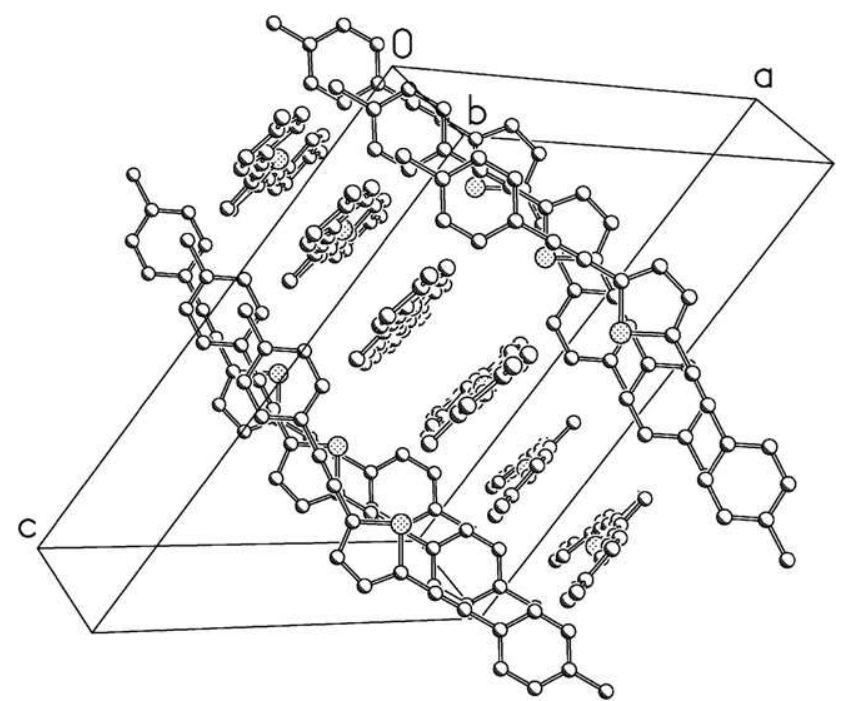

Fig. 8 Crystal packing of $\mathbf{1 b}$ (hydrogen atoms are omitted).

the phenyl and thiophene rings of the next. The stacks are arranged into a layer parallel to the $(10-2)$ plane (Fig. 8). The adjacent layers, related by the screw axis, are obviously parallel, and the directions of the stacks in these layers, $\left[\begin{array}{lll}1 & 0 & 0\end{array}\right]$, are also parallel. However, both the mean planes and the long axes of the molecules belonging to adjacent layers are practically perpendicular (angles 89 and $88^{\circ}$, respectively). The packing of $\mathbf{2}$ is similar, albeit that in this case, the stacked molecules are related by the $a$ translation, with $d=3.49 \AA$ and $\theta=45.0^{\circ}$. The planes of molecules belonging to adjacent layers form an angle of $75^{\circ}$, and their long axes are staggered by $85^{\circ}$. In 1a, the corresponding angles are 70 and $85^{\circ}$, but the intra-stack slip is larger $\left(\theta=54.9^{\circ}\right)$ and more laterally directed. Thus, the overlap of molecules within a 'stack' (generated, as in $\mathbf{1 b}$, by the $b$ translation) is actually slight, even though $d$ is as short as $3.30 \AA$. In contrast, the more linear molecules of $\mathbf{1 h}$ pack in a slanted herringbone manner into a layer, in which the planes of contacting molecules meet at a $45^{\circ}$ angle (Fig. 9). The long axes of all molecules within a layer are parallel to one another and inclined by $c a .24^{\circ}$ to the crystallographic axis $a$, which is normal to the mean plane of the layer.

\section{DFT calculations on $1 \mathrm{a}-\mathrm{h}$ and 2}

We have performed DFT and TD-DFT calculations on all of the BPETs using the B3LYP functional and the 6-31G* basis

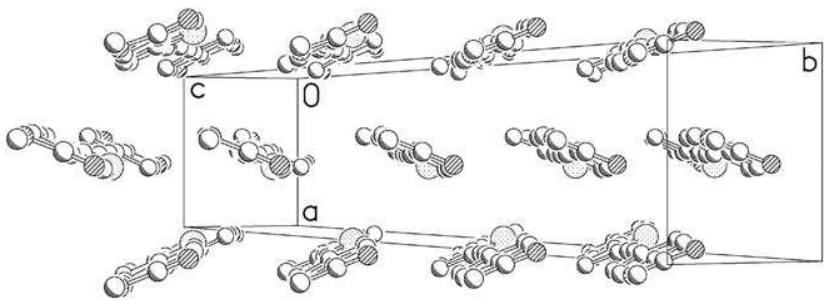

Fig. 9 Crystal packing of $\mathbf{1 h}$, viewed down the long axis of the molecule. set, as defined in Gaussian03, ${ }^{47}$ for all atoms. Geometries were optimised for all compounds, and in all cases, a coplanar arrangement of the aryl and thiophene rings was found to be the lowest in energy, as has been observed previously for BPEBs. ${ }^{13,15 b}$ Details of the computed bond distances for compounds $\mathbf{1 a , b , h}$ and $\mathbf{2}$ are given in Table 2, for comparison with the experimental values determined from the X-ray diffraction experiments. All of the computed distances are within $1.5 \%$ of their experimental counterparts, and most are within $1 \%$. We also performed vibration frequency calculations on all of the optimised geometries, indicating that they are indeed minima. The frequency calculations also allowed us to assign the compounds' absorptions in their IR and Raman spectra, especially the symmetric stretching mode of the two $\mathrm{C} \equiv \mathrm{C}$ units, which gives rise to a strong band in each of the Raman spectra, and its asymmetric counterpart, which leads to a strong band in the IR spectra. We note that the correction factor for the calculated frequencies in both the IR and Raman spectra is 0.96 in all cases, in excellent agreement with that normally observed for DFT calculations with this combination of functional and basis set. ${ }^{48}$ Even though the compounds all have $C_{2 \mathrm{v}}$ geometries, and thus lack inversion centres, due to the nature of the angles that the $\mathrm{C} \equiv \mathrm{C}$ vectors make with the thienyl rings, there is clearly little change in dipole moment for the symmetric $\mathrm{C} \equiv \mathrm{C}$ stretching mode and little change in polarisability for the asymmetric $\mathrm{C} \equiv \mathrm{C}$ stretching mode, as these bands are predicted to be very weak in the IR and Raman spectra, respectively, and are not observed experimentally. Also of interest is the fact that the two bands are calculated to be $c a .10 \mathrm{~cm}^{-1}$ apart, with the IRactive asymmetric stretching mode always being predicted to be at a slightly higher energy. However, in the experimental spectra, these bands are almost coincident in energy, within experimental error. Although we have not computed barriers to rotation about the $\mathrm{C}_{\mathrm{aryl}}-\mathrm{C}_{\text {alkynyl }}$ bonds, these are expected to be quite small in both solution and the gas phase, again, in line with what has been found previously for BPEBs, ${ }^{13}$ and consistent with the fact that various torsion angles (up to $33.6^{\circ}$, see Table 2) are observed in the solid-state structures, vide supra. The frequency calculations show very low energy modes corresponding to this rotational motion, as well as to a bending mode which changes the angle between the two $\mathrm{C} \equiv \mathrm{C}$ vectors.

Gas phase TD-DFT calculations permitted assignment of the lowest energy allowed $\mathrm{S}_{1} \leftarrow \mathrm{S}_{0}$ electronic absorptions in the UV-vis spectra to the HOMO-LUMO transition in all cases, and these are predicted to have large oscillator strengths ( $f=c a$. 1.5-1.9), corresponding to the observed large extinction coefficients, which are in the range ca. 33000-52000 $\mathrm{mol}^{-1} \mathrm{~cm}^{-1} \mathrm{dm}^{3}$ (Table 1). The calculated $\mathrm{S}_{1} \leftarrow \mathrm{S}_{0}$ absorptions are 41-45 $\mathrm{nm}$ red-shifted from the observed values of $\lambda_{\max }$ for $\mathbf{1 a - e}$ and $\mathbf{2}$, and 65,55 and $56 \mathrm{~nm}$ red-shifted for $\mathbf{1 f}-\mathbf{h}$, respectively, which is a result of the increased $\pi$-conjugation in the planar structures found in the calculations. In solution, nearly free rotation around the $\mathrm{C} \equiv \mathrm{C}$ bonds leads to Frank-Condon absorption arising from a weighted average of all rotamers. ${ }^{13,15 b}$ Thus, it is known ${ }^{13,15 b}$ that at ambient temperature, the observed absorption profile is blue-shifted due to the presence of rotational isomers, in which the $\mathrm{S}_{1} \leftarrow \mathrm{S}_{0}$ 
transition energies increase with the torsion angle between adjacent rings. Note that $\pi$-conjugation falls off with $\cos ^{2} \theta$. However, the positions of the 0,0 transitions can be estimated from the absorption and emission spectra. Low temperature spectra of 1a reveal the presence of an intense 0,0 transition of the planar conformation, which is virtually coincident with the emission maximum; in non-polar solvents, the 0,0 bands show a negligible Stokes shift. ${ }^{39}$ Thus, in Table 1, we collect the observed transition energies in solution (using the emission maxima), along with those calculated from the TD-DFT studies in the gas phase. The observed and calculated values are generally in good agreement, with the observed values typically being $600-900 \mathrm{~cm}^{-1}$ ( $\mathrm{ca} .3-4 \%$ ) higher in energy than the calculated ones. The notable exceptions are the $\mathrm{NMe}_{2}$ compound, 1e, for which the observed value is actually 300 $\mathrm{cm}^{-1}$ lower in energy than the calculated one, and the $\mathrm{NO}_{2}$ compound, 1f, for which the observed value is $1400 \mathrm{~cm}^{-1}$ higher in energy than the observed value. These larger discrepancies could well be a result of solvation effects, which are more important for the cases wherein there is a larger degree of charge transfer, vide infra. We note that a TD-DFT calculation on 1f, in which both nitrophenyl groups have been rotated by $45^{\circ}$ (in the same direction), leads to a $10 \mathrm{~nm}$ blue shift in the absorption energy, along with a reduction in the oscillator strength. In contrast, rotating one of the nitrophenyl groups by $90^{\circ}$ leads to a $44 \mathrm{~nm}$ blue shift. Interestingly, when both nitrophenyl groups are rotated by $90^{\circ}$, effectively decoupling their $\pi$-systems from the diethynylthiophene core, the HOMO-LUMO transition has an oscillator strength of 0 and the lowest energy absorption is shifted by $133 \mathrm{~nm}$. The conjugation effect is smaller for the donor-substituted and weakly acceptor-substituted systems than it is for the strong acceptor compounds, increasing with acceptor strength. This is also in keeping with the steeper slopes of the Hammett plots for the acceptors compared to the donors shown in Fig. 6. There is no significant charge transfer evident in the $\mathrm{S}_{1} \leftarrow \mathrm{S}_{0}$ transition of the parent compound 1a (see HOMO and LUMO in Fig. 10). In contrast, some degree of charge transfer is evident for the donor cases, wherein the HOMO has a significant contribution from the para-substituent, whereas the LUMO is more localised in the centre of the molecule (e.g. $\mathrm{NMe}_{2}$ compound 1e in Fig. 10). Likewise, for the acceptors (e.g. $\mathrm{NO}_{2}$ compound $\mathbf{1 f}$ in Fig. 10), we see the inverse charge transfer, with the HOMO being more localised at the centre of the molecule and the LUMO having significant $\mathrm{NO}_{2}$ character. We confirmed the charge transfer by computing the contributions of each moiety (thienylene, ethynyl, phenylene and para-substituent) to the HOMO and LUMO. Consistent with this is the small red shift $(7 \mathrm{~nm})$ in the absorption maximum for 1f when the solvent is changed from toluene to $\mathrm{CH}_{2} \mathrm{Cl}_{2}$, although the emission maximum red-shifts by $112 \mathrm{~nm}$, giving rise to a large Stokes shift of $7100 \mathrm{~cm}^{-1}$ in $\mathrm{CH}_{2} \mathrm{Cl}_{2}$, indicating a substantial electronic/structural reorganisation in the singlet excited state prior to emission, especially in more polar solvents, which are capable of better stabilising the accompanying charge redistribution. Further details on the structure of the excited state of 1a and its photophysics (in both singlet and triplet states) can be found in a companion paper. $^{39}$
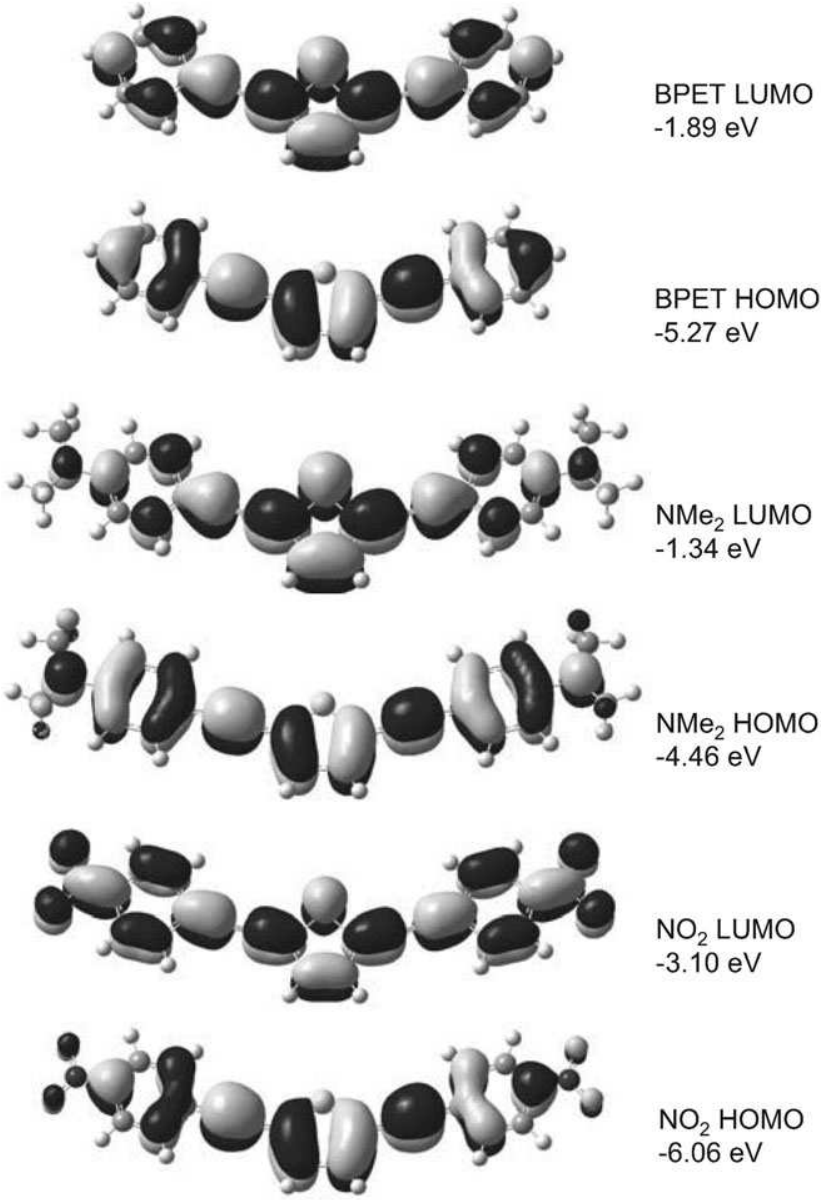

$\mathrm{NO}_{2} \mathrm{HOMO}$

$-6.06 \mathrm{eV}$

Fig. 10 Plots of the HOMO and LUMO for compounds 1a (BPET), 1e $\left(\mathrm{NMe}_{2}\right)$ and $\mathbf{1 f}\left(\mathrm{NO}_{2}\right)$, and their respective energies.

\section{Conclusions}

We have shown that the $\mathrm{Pd} / \mathrm{Cu}$-catalysed Sonogashira crosscoupling methodology provides a convenient route to a series of para-substituted 2,5-bis(phenylethynyl)thiophenes. These chromophores show interesting photophysical properties, which have been studied in solution at room temperature. The presence of strong donors or acceptors is found to redshift both the absorption and emission bands. The compounds have the moderate quantum yields and short singlet lifetimes characteristic of rapid intersystem crossing to the triplet state. $^{36}$

\section{Experimental}

\section{General}

All reactions were performed under dry nitrogen using standard Schlenk techniques. The amine solvents used in syntheses were dried over $\mathrm{CaH}_{2}$ and distilled under dry nitrogen. Reagents purchased from commercial suppliers were tested for purity by GC-MS before use. Ethynylbenzenes were synthesised by literature methods, ${ }^{49}$ except for phenylacetylene, which was purchased from Aldrich. Crude yields of $c a$. $80 \pm 15 \%$ were typical. As we required high purities for 
spectroscopic measurements, the yields reported here are of analytically pure material, obtained after one or more recrystallisations.

Reactions were monitored in situ by GC-MS or by TLC to assure the complete disappearance of 2,5-diiodothiophene prior to workup. GC-MS analyses were performed on an Agilent Technologies $6890 \mathrm{~N}$ gas chromatograph equipped with a 5973 inert mass selective detector and a $10 \mathrm{~m}$ fused silica capillary column ( $5 \%$ cross-linked phenylmethylsilicone) under the following operating conditions: injector temperature $250{ }^{\circ} \mathrm{C}$, detector temperature $300{ }^{\circ} \mathrm{C}$, the oven temperature was ramped from 70 to $280{ }^{\circ} \mathrm{C}$ at $20{ }^{\circ} \mathrm{C} \mathrm{min}{ }^{-1}$. UHP helium was used as the carrier gas. NMR spectra were recorded in $\mathrm{CDCl}_{3}$ on Varian Mercury-200, Unity-300 and Inova-500, and Bruker Avance-400 spectrometers at the following frequencies: ${ }^{1} \mathrm{H}: 200,300$ and $400 \mathrm{MHz},{ }^{13} \mathrm{C}\left\{{ }^{1} \mathrm{H}\right\}: 100$ and $126 \mathrm{MHz}$, ${ }^{19} \mathrm{~F}\left\{{ }^{1} \mathrm{H}\right\}: 188 \mathrm{MHz} .{ }^{13} \mathrm{C}$ NMR assignments were made with the assistance of HSQC and HMBC experiments. Mass spectra for compounds 1a-d, $\mathbf{1 g}$ and $\mathbf{2}$ were obtained on a Thermo Finnigan Trace MS spectrometer operating in EI mode. Spectra for 1e, 1f and 1i were obtained on a Thermo Finnigan DSQ spectrometer operating in EI mode. Elemental analyses were performed using an Exeter Analytical E440 machine by departmental services at Durham University. Melting point values were measured on a Stuart Scientific SM3 apparatus. IR spectra were recorded as $\mathrm{KBr}$ disks using a Perkin-Elmer Spectrum 100 series FT-IR spectrometer. Raman spectra were recorded on solid samples using a Horiba Jobin Yvon LabRamHR Raman microscope with the laser set at $785 \mathrm{~nm}$.

UV-vis, fluorescence spectra, lifetime and quantum yield measurements were recorded in toluene if not indicated otherwise. UV-vis absorption spectra and extinction coefficients were obtained on a Hewlett-Packard 8453 diode array spectrophotometer using standard $1 \mathrm{~cm}$ width quartz cells. Fluorescence spectra and quantum yield measurements were recorded on a Horiba Jobin Yvon Fluorolog FL 3-22 Tau spectrophotometer. The spectra of dilute solutions, with absorbance maxima of less than 0.1 , were recorded using a conventional $90^{\circ}$ geometry. The emission spectra were fully corrected using the manufacturer's correction curves for the spectral response of the emission optical components. The quantum yield of each compound was estimated by comparing it with standards of known quantum yield. The absorbance of the sample was kept below 0.12 to avoid inner filter effects, and all measurements were carried out at room temperature. The fluorescence quantum yields of compounds $\mathbf{1 a - d}, \mathbf{1 g}, \mathbf{1 i}$ and $\mathbf{2}$ were measured against 1,4-di-(5-phenyl-1,3-oxazole-2-yl)-benzene (POPOP $)$ in cyclohexane $(\Phi=0.97)^{50}$ and quinine sulfate in $0.1 \mathrm{M}$ $\mathrm{H}_{2} \mathrm{SO}_{4}(\Phi=0.54),{ }^{50}$ and that of $1 \mathrm{e}$ and 1f were measured against norharmane in $0.1 \mathrm{M} \mathrm{H}_{2} \mathrm{SO}_{4}(\Phi=0.58)^{51}$ and 9,10diphenylanthracene in $\mathrm{C}_{6} \mathrm{H}_{12}(\Phi=0.9) .{ }^{50}$ The fluorescence lifetimes of $\mathbf{1 a}-\mathbf{e}, \mathbf{1 g}, \mathbf{1} \mathbf{i}$ and $\mathbf{2}$ were measured by time-correlated single photon counting (TCSPC) using either a $396 \mathrm{~nm}$ pulsed laser diode or the 3rd harmonic of a cavity-dumped, mode-locked Ti-sapphire laser (Coherent MIRA, $300 \mathrm{~nm}$ ). The fluorescence emission was collected at right angles to the excitation source, with the emission wavelength selected using a monochromator and detected by a single photon avalanche diode (SPAD). The instrument response function was mea- sured using a dilute LUDOX ${ }^{\circledR}$ suspension as the scattering sample, setting the monochromator at the emission wavelength of the laser, giving an instrument response function (IRF) of 200 or 100 ps at 396 or $300 \mathrm{~nm}$, respectively. The resulting intensity decay was a convolution of the fluorescence decay with the IRF, and iterative reconvolution of the IRF with a decay function and non-linear least-squares analysis were used to analyse the convoluted data. ${ }^{50,52,53}$

\section{Syntheses}

2,5-Bis(phenylethynyl)thiophene (1a). The compounds 2,5diiodothiophene $(0.67 \mathrm{~g}, 2.00 \mathrm{mmol}), \mathrm{Pd}\left(\mathrm{PPh}_{3}\right)_{2} \mathrm{Cl}_{2}(0.03 \mathrm{~g}$, $0.04 \mathrm{mmol})$ and $\mathrm{CuI}(0.008 \mathrm{~g}, 0.04 \mathrm{mmol})$ were added to a Schlenk flask that had been evacuated and refilled with nitrogen three times. Dry, de-gassed $\mathrm{NEt}_{3}(50 \mathrm{~mL})$ was added via a cannula. Phenylacetylene ( $0.43 \mathrm{~g}, 4.20 \mathrm{mmol})$ was then added under a positive pressure of nitrogen and the reaction mixture was stirred at room temperature for $72 \mathrm{~h}$. The $\mathrm{NEt}_{3}$ solvent was then removed in vacuo. The residual solid was applied to the top of a $5 \mathrm{~cm}$ silica gel column eluted with hot toluene. The toluene was removed in vacuo and the product was recrystallised from a toluene/hexane solution. Yield of analytically pure material $0.15 \mathrm{~g}(26 \%)$, m.p. $83.9-84.5{ }^{\circ} \mathrm{C}$. IR $\left(/ \mathrm{cm}^{-1}\right)$ 1595 (arene ring), 2199 (C $\equiv \mathrm{C}$, asym). Raman $\left(/ \mathrm{cm}^{-1}\right) 1445$, 1595 (arene ring), 2198 (C $\equiv \mathrm{C}$, sym). ${ }^{1} \mathrm{H}$ NMR (400 MHz): $\delta$ $7.54\left(\mathrm{~m}, 4 \mathrm{H}, \mathrm{CH}_{\text {arom }}\right), 7.36\left(\mathrm{~m}, 6 \mathrm{H}, \mathrm{CH}_{\text {arom }}\right), 7.17(\mathrm{~s}, 2 \mathrm{H}$, $\left.\mathrm{CH}_{\text {thiophene }}\right) .{ }^{13} \mathrm{C}\left\{{ }^{1} \mathrm{H}\right\}$ NMR $(100 \mathrm{MHz}): \delta 131.82\left(\mathrm{C}_{\text {thio }}\right)$, $131.50\left(\mathrm{C}_{\text {arom }}\right), 128.67\left(\mathrm{C}_{\text {arom }}\right), 128.42\left(\mathrm{C}_{\text {arom }}\right), 124.68\left(\mathrm{C}_{\text {thio }}\right)$, $122.63\left(\mathrm{C}_{\text {arom }}\right), 94.07(\mathrm{C} \equiv \mathrm{C}), 82.28(\mathrm{C} \equiv \mathrm{C})$. MS $(\mathrm{EI}): m / z$ 284. Anal. calc. for $\mathrm{C}_{20} \mathrm{H}_{12} \mathrm{~S}: \mathrm{C}, 84.47 ; \mathrm{H}, 4.25$. Found: C, $84.09 ; \mathrm{H}, 4.14 \%$.

2,5-Bis(para-methylphenylethynyl)thiophene (1b). The compounds 2,5-diiodothiophene $(0.67 \mathrm{~g}, \quad 2.00 \mathrm{mmol})$, $\mathrm{Pd}\left(\mathrm{PPh}_{3}\right)_{2} \mathrm{Cl}_{2}(0.03 \mathrm{~g}, 0.04 \mathrm{mmol})$ and $\mathrm{CuI}(0.008 \mathrm{~g}, 0.04$ mmol) were added under nitrogen to a Schlenk flask. Dry, de-gassed $\mathrm{NEt}_{3}(50 \mathrm{~mL})$ was added via a cannula. 4-Methylphenylacetylene $(0.49 \mathrm{~g}, 4.20 \mathrm{mmol})$ was then added under a positive pressure of nitrogen. The reaction mixture was stirred at room temperature for $24 \mathrm{~h}$ and the $\mathrm{NEt}_{3}$ was then removed in vacuo. The residual solid was applied to the top of a $5 \mathrm{~cm}$ silica gel column eluted with $1: 1 \mathrm{CH}_{2} \mathrm{Cl}_{2} /$ hexane, and the solvent was removed in vacuo. Analytically pure product was obtained as a red crystalline solid after recrystallisation from a hot hexane/toluene solution. Yield $0.17 \mathrm{~g}$ (27\%), m.p. 167.9-168.2 ${ }^{\circ} \mathrm{C}$. IR $\left(/ \mathrm{cm}^{-1}\right) 1530$ (arene ring), $2192(\mathrm{C} \equiv \mathrm{C}$, asym). Raman (/cm $\left.{ }^{-1}\right)$ 1438, 1604, (arene ring), $2195(\mathrm{C} \equiv \mathrm{C}$, sym). ${ }^{1} \mathrm{H}$ NMR (200 MHz): $\delta 7.43$ (d, $\left.J=8 \mathrm{~Hz}, 4 \mathrm{H}, \mathrm{CH}_{\text {arom }}\right)$, 7.17 (d, $\left.J=8 \mathrm{~Hz}, 4 \mathrm{H}, \mathrm{CH}_{\text {arom }}\right), 7.14$ (s, $\left.2 \mathrm{H}, \mathrm{CH}_{\text {thiophene }}\right), 2.38$ (s, $\left.6 \mathrm{H}, \mathrm{CH}_{3}\right) \cdot{ }^{13} \mathrm{C}\left\{{ }^{1} \mathrm{H}\right\}$ NMR $(100 \mathrm{MHz}): \delta 138.89\left(\mathrm{C}_{\text {arom }}\right)$, $131.56\left(\mathrm{C}_{\text {thio }}\right), 131.39\left(\mathrm{C}_{\text {arom }}\right), 129.18\left(\mathrm{C}_{\text {arom }}\right), 124.69\left(\mathrm{C}_{\text {thio }}\right)$, $119.57\left(\mathrm{C}_{\text {arom }}\right), 94.19(\mathrm{C} \equiv \mathrm{C}), 81.71(\mathrm{C} \equiv \mathrm{C}), 21.54\left(\mathrm{CH}_{3}\right)$. MS (EI): $m / z$ 312. Anal. calc. for $\mathrm{C}_{22} \mathrm{H}_{16} \mathrm{~S}: \mathrm{C}, 84.57 ; \mathrm{H}, 5.16$. Found: C, 84.68; H, 5.16\%.

2,5-Bis(para-methoxyphenylethynyl)thiophene (1c). The compounds 2,5-diiodothiophene $(0.67 \mathrm{~g}, 2.00 \mathrm{mmol})$, $\mathrm{Pd}\left(\mathrm{PPh}_{3}\right)_{2} \mathrm{Cl}_{2}(0.03 \mathrm{~g}, 0.04 \mathrm{mmol})$ and $\mathrm{CuI}(0.008 \mathrm{~g}, 0.04$ $\mathrm{mmol})$ were added under nitrogen to a Schlenk flask. Dry, 
de-gassed $\mathrm{NEt}_{3}(50 \mathrm{~mL})$ was added via a cannula and 4methoxyphenylacetylene $(0.55 \mathrm{~g}, 4.20 \mathrm{mmol})$ was then added under a positive pressure of nitrogen. The reaction mixture was stirred at room temperature for $72 \mathrm{~h}$ and the $\mathrm{NEt}_{3}$ was then removed in vacuo. The residual solid was added to the top of a $5 \mathrm{~cm}$ silica gel column eluted with $1: 1 \mathrm{CH}_{2} \mathrm{Cl}_{2} /$ hexane. The solvents were removed in vacuo. Recrystallisation of the crude product from hot toluene/ $\mathrm{CH}_{2} \mathrm{Cl}_{2}$ gave a bright yellow, analytically pure solid. Yield: $0.23 \mathrm{~g},(34 \%)$, m.p. $119.6-122.4{ }^{\circ} \mathrm{C}$. IR (/ $\left.\mathrm{cm}^{-1}\right) 1602$ (arene ring), $2198(\mathrm{C} \equiv \mathrm{C}$, asym). Raman (/ $\mathrm{cm}^{-1}$ ) 1441, 1607 (arene ring), $2197\left(\mathrm{C} \equiv \mathrm{C}\right.$, sym). ${ }^{1} \mathrm{H}$ NMR (200 MHz): $\delta 7.46$ (d, $\left.J=9 \mathrm{~Hz}, 4 \mathrm{H}, \mathrm{CH}_{\text {arom }}\right), 7.11(\mathrm{~s}, 2 \mathrm{H}$, $\left.\mathrm{CH}_{\text {thiophene }}\right), 6.88\left(\mathrm{~d}, J=9 \mathrm{~Hz}, 4 \mathrm{H}, \mathrm{CH}_{\text {arom }}\right), 3.84(\mathrm{~s}, 6 \mathrm{H}$, $\left.\mathrm{OCH}_{3}\right) .{ }^{13} \mathrm{C}\left\{{ }^{1} \mathrm{H}\right\}$ NMR (100 MHz): $\delta 159.95\left(\mathrm{C}_{\mathrm{arom}}\right), 133.03$ $\left(\mathrm{C}_{\text {arom }}\right), 131.33\left(\mathrm{C}_{\text {thio }}\right), 124.64\left(\mathrm{C}_{\text {thio }}\right), 114.75\left(\mathrm{C}_{\text {arom }}\right), 114.10$ $\left(\mathrm{C}_{\text {arom }}\right), 93.95(\mathrm{C} \equiv \mathrm{C}), 81.11(\mathrm{C} \equiv \mathrm{C}), 55.33\left(\mathrm{OCH}_{3}\right) . \mathrm{MS}$ (EI): $m / z$ 344. Anal. calc. for $\mathrm{C}_{22} \mathrm{H}_{16} \mathrm{O}_{2} \mathrm{~S}: \mathrm{C}, 76.72 ; \mathrm{H}, 4.68$. Found: $\mathrm{C}, 76.52 ; \mathrm{H}, 4.65 \%$.

\section{2,5-Bis(para-trifluoromethylphenylethynyl)thiophene}

(1d). The compounds 2,5-diiodothiophene $(0.67 \mathrm{~g}, 2.00 \mathrm{mmol})$, $\mathrm{Pd}\left(\mathrm{PPh}_{3}\right)_{2} \mathrm{Cl}_{2}(0.03 \mathrm{~g}, 0.04 \mathrm{mmol})$ and $\mathrm{CuI}(0.008 \mathrm{~g}, 0.04$ mmol) were added under nitrogen to a Schlenk flask. Dry, de-gassed $\mathrm{NEt}_{3}(50 \mathrm{~mL})$ was added via a cannula and 4trifluoromethylphenylacetylene $(0.72 \mathrm{~g}, 4.20 \mathrm{mmol})$ was then added under a positive pressure of nitrogen. The reaction mixture was stirred at room temperature for $94 \mathrm{~h}$ and the $\mathrm{NEt}_{3}$ was then removed in vacuo. The residual solid was added to the top of a $5 \mathrm{~cm}$ silica gel column eluted with hexane and the solvent was removed in vacuo. The solid was recrystallised from a small amount of hot hexane to give a yellow, analytically pure, crystalline solid. Yield: $0.50 \mathrm{~g}$ (60\%), m.p. 107.8-112.2 ${ }^{\circ} \mathrm{C}$. IR (/ $\left.\mathrm{cm}^{-1}\right) 1609$ (arene ring), $2197(\mathrm{C} \equiv \mathrm{C}$, asym). Raman (/cm $\left.{ }^{-1}\right)$ 1442, 1617 (arene ring), $2202(\mathrm{C} \equiv \mathrm{C}$, sym). ${ }^{1} \mathrm{H}$ NMR (200 MHz): $\delta 7.62\left(\mathrm{~s}, 8 \mathrm{H}, \mathrm{CH}_{\text {arom}}\right), 7.23$ (s, 2 $\left.\mathrm{H}, \mathrm{CH}_{\text {thiophene }}\right){ }^{19} \mathrm{~F}\left\{{ }^{1} \mathrm{H}\right\} \mathrm{NMR}(188 \mathrm{~Hz}): \delta-63.28(\mathrm{~s}, 6 \mathrm{~F}$, $\left.\mathrm{CF}_{3}\right) \cdot{ }^{13} \mathrm{C}\left\{{ }^{1} \mathrm{H}\right\}$ NMR $(126 \mathrm{MHz}): \delta 132.88\left(\mathrm{C}_{\text {thio }}\right), 131.91$ $\left(\mathrm{C}_{\text {arom}}\right), 130.57$ (q, $\left.J_{\mathrm{CF}}=33 \mathrm{~Hz}, \mathrm{C}_{\text {arom }}\right), 126.53\left(\mathrm{C}_{\text {arom }}\right)$, $125.62\left(\mathrm{q}, J_{\mathrm{CF}}=3 \mathrm{~Hz}, \mathrm{C}_{\text {arom }}\right), 124.83\left(\mathrm{C}_{\text {thio }}\right), 124.10\left(\mathrm{q}, J_{\mathrm{CF}}\right.$ $\left.=272 \mathrm{~Hz}, \mathrm{CF}_{3}\right), 92.95(\mathrm{C} \equiv \mathrm{C}), 84.41(\mathrm{C} \equiv \mathrm{C})$. MS (EI): $m / z$ 420. Anal. calc. for $\mathrm{C}_{22} \mathrm{H}_{10} \mathrm{~F}_{6} \mathrm{~S}: \mathrm{C}, 62.86 ; \mathrm{H}, 2.40$. Found: $\mathrm{C}$, $62.65 ; \mathrm{H}, 2.39 \%$.

2,5-Bis(para- $N, N$-dimethylaminophenylethynyl)thiophene (1e). The compounds 2,5-diiodothiophene $(0.58 \mathrm{~g}, 1.72 \mathrm{mmol})$, $\mathrm{Pd}\left(\mathrm{PPh}_{3}\right)_{2} \mathrm{Cl}_{2}(0.024 \mathrm{~g}, 0.034 \mathrm{mmol})$ and $\mathrm{CuI}(0.006 \mathrm{~g}, 0.034$ $\mathrm{mmol}$ ) were added under nitrogen to a Schlenk flask. Dry, degassed $\mathrm{NEt}_{3}(50 \mathrm{~mL})$ was added via a cannula and $4-N, N$ dimethylaminophenylacetylene $(0.53 \mathrm{~g}, 3.62 \mathrm{mmol})$ was then added under a positive pressure of nitrogen. The reaction mixture was stirred at room temperature for $96 \mathrm{~h}$ and the $\mathrm{NEt}_{3}$ was then removed in vacuo. The residual solid was added to the top of a $5 \mathrm{~cm}$ alumina pad, which was first eluted with hexane $(150 \mathrm{ml})$ to remove any unreacted starting materials. The column was eluted with $1: 4 \mathrm{CH}_{2} \mathrm{Cl}_{2}$ /hexane and the solvents were then removed in vacuo. The product was recrystallised from $\mathrm{CH}_{2} \mathrm{Cl}_{2} /$ hexanes to yield a bright yellow solid. Yield 0.25 g (39\%), m.p. 194.4-198.0 ${ }^{\circ} \mathrm{C}$. IR $\left(/ \mathrm{cm}^{-1}\right) 1531$, 1605 (arene ring), $2194\left(\mathrm{C} \equiv \mathrm{C}\right.$, asym). Raman $\left(/ \mathrm{cm}^{-1}\right) 1257$,
1452, 1609 (arene ring), $2192\left(\mathrm{C} \equiv \mathrm{C}\right.$, sym). ${ }^{1} \mathrm{H}$ NMR (300 $\mathrm{MHz}): \delta 7.39\left(\mathrm{~d}, J=9 \mathrm{~Hz}, 4 \mathrm{H}, \mathrm{CH}_{\text {arom }}\right), 7.05$ (s, $2 \mathrm{H}$, $\left.\mathrm{CH}_{\text {thiophene }}\right), 6.65$ (d, $\left.J=9 \mathrm{~Hz}, 4 \mathrm{H}, \mathrm{CH}_{\text {arom }}\right), 3.00(\mathrm{~s}, 12 \mathrm{H}$, $\left.\mathrm{N}\left(\mathrm{CH}_{3}\right)_{2}\right) .{ }^{13} \mathrm{C}\left\{{ }^{1} \mathrm{H}\right\} \mathrm{NMR}(100 \mathrm{MHz}): \delta 150.46\left(\mathrm{C}_{\text {arom }}\right), 132.89$ $\left(\mathrm{C}_{\text {arom }}\right), 130.98$ ( $\left.\mathrm{C}_{\text {thio }}\right), 124.90\left(\mathrm{C}_{\text {thio }}\right), 111.98\left(\mathrm{C}_{\text {arom }}\right), 109.52$ $\left(\mathrm{C}_{\text {arom }}\right), 95.29(\mathrm{C} \equiv \mathrm{C}), 80.78(\mathrm{C} \equiv \mathrm{C}), 40.41\left(\mathrm{~N}\left(\mathrm{CH}_{3}\right)_{2}\right) . \mathrm{MS}$ (EI): $m / z$ 370. Anal. calc. for $\mathrm{C}_{24} \mathrm{H}_{22} \mathrm{~N}_{2} \mathrm{~S}: \mathrm{C}, 77.80 ; \mathrm{H}, 5.98 ; \mathrm{N}$, 7.56. Found: C, 77.29; H, 5.91; N, 7.57\%.

2,5-Bis(para-nitrophenylethynyl)thiophene (1f). The compounds 2,5-diiodothiophene (1.34 g, $4.00 \mathrm{mmol})$, $\mathrm{Pd}\left(\mathrm{PPh}_{3}\right)_{2} \mathrm{Cl}_{2}(0.056 \mathrm{~g}, 0.08 \mathrm{mmol})$ and $\mathrm{CuI}(0.015 \mathrm{~g}, 0.08$ mmol) were added under nitrogen to a Schlenk flask. Dry, degassed $\mathrm{NEt}_{3}(50 \mathrm{~mL})$ was added via a cannula and 4-nitrophenylacetylene $(1.24 \mathrm{~g}, 8.40 \mathrm{mmol})$ was then added under a positive pressure of nitrogen. The reaction mixture was stirred at room temperature for $72 \mathrm{~h}$ and the $\mathrm{NEt}_{3}$ was then removed in vacuo. The residual solid was added to the top of a $5 \mathrm{~cm}$ silica gel column eluted with $1: 1 \mathrm{CH}_{2} \mathrm{Cl}_{2} /$ hexane and the solvents were removed in vacuo. Analytically pure product was obtained as a gold coloured solid after two recrystallisations from hot toluene. Yield: $0.84 \mathrm{~g}(56 \%)$, m.p. $193.9-195.6^{\circ} \mathrm{C}$. IR $\left(/ \mathrm{cm}^{-1}\right) 1333\left(\mathrm{NO}_{2}\right.$, asym), 1511, 1591 (arene ring), 2200 $\left(\mathrm{C} \equiv \mathrm{C}\right.$, asym). Raman $\left(/ \mathrm{cm}^{-1}\right) 1329\left(\mathrm{NO}_{2}, \mathrm{sym}\right), 1589$ (arene ring), 2195 (C $\equiv \mathrm{C}$, sym). ${ }^{1} \mathrm{H}$ NMR (200 MHz): $\delta 8.25$ (d, $J=$ $9 \mathrm{~Hz}, 4 \mathrm{H}, \mathrm{CH}_{\text {arom }}$ ), 7.68 (d, $\left.J=9 \mathrm{~Hz}, 4 \mathrm{H}, \mathrm{CH}_{\text {arom }}\right), 7.28$ (s, 2 $\left.\mathrm{H}, \mathrm{CH}_{\text {thiophene }}\right) \cdot{ }^{13} \mathrm{C}\left\{{ }^{1} \mathrm{H}\right\}$ NMR $(100 \mathrm{MHz}): \delta 147.30\left(\mathrm{C}_{\text {arom }}\right)$, $133.23\left(\mathrm{C}_{\text {thio }}\right), 132.14\left(\mathrm{C}_{\text {arom }}\right), 129.25\left(\mathrm{C}_{\text {arom }}\right), 124.72\left(\mathrm{C}_{\text {thio }}\right)$, $123.75\left(\mathrm{C}_{\text {arom }}\right), 92.83(\mathrm{C} \equiv \mathrm{C}), 87.10(\mathrm{C} \equiv \mathrm{C})$. MS (EI): $m / z$ 374. Anal. calc. for $\mathrm{C}_{20} \mathrm{H}_{10} \mathrm{~N}_{2} \mathrm{O}_{4} \mathrm{~S}$ : C, 64.16; H, 2.69; N, 7.48. Found: C, 64.19; H, 2.63; N, 7.35\%.

2,5-Bis(para-cyanophenylethynyl)thiophene (1g). The compounds 2,5-diiodothiophene $(0.67 \mathrm{~g}, 2.00 \mathrm{mmol})$, $\mathrm{Pd}\left(\mathrm{PPh}_{3}\right)_{2} \mathrm{Cl}_{2}(0.03 \mathrm{~g}, 0.04 \mathrm{mmol})$ and $\mathrm{CuI}(0.008 \mathrm{~g}, 0.04$ $\mathrm{mmol})$ were added under nitrogen to a Schlenk flask. Dry, de-gassed $\mathrm{NHEt}_{2}(50 \mathrm{~mL})$ was added via a cannula and 4cyanophenylacetylene $(0.53 \mathrm{~g}, 4.20 \mathrm{mmol})$ was then added under a positive pressure of nitrogen. The reaction mixture was stirred at room temperature for $63 \mathrm{~h}$ and the $\mathrm{NHEt}_{2}$ was removed in vacuo. The residual solid was added to the top of a $5 \mathrm{~cm}$ silica gel column eluted with $1: 1 \mathrm{CH}_{2} \mathrm{Cl}_{2} /$ hexane and the solvents were removed in vacuo. Analytically pure product was obtained as a tan solid after two recrystallisations from hot toluene. Yield: $0.23 \mathrm{~g}(34 \%)$, m.p. $250.6-252.6^{\circ} \mathrm{C}$. IR $\left(/ \mathrm{cm}^{-1}\right)$ 1597 (arene ring), $2202(\mathrm{C} \equiv \mathrm{C}$, sym), $2226(\mathrm{C} \equiv \mathrm{N}$, sym). Raman (/cm ${ }^{-1}$ ) 1436, 1602 (arene ring), 2197 (C $\equiv \mathrm{C}$, asym). ${ }^{1} \mathrm{H}$ NMR (200 MHz): $\delta 7.63\left(\mathrm{~m}, 8 \mathrm{H}, \mathrm{CH}_{\text {arom }}\right), 7.24(\mathrm{~s}, 2 \mathrm{H}$, $\left.\mathrm{CH}_{\text {thiophene }}\right) .{ }^{13} \mathrm{C}\left\{{ }^{1} \mathrm{H}\right\}$ NMR $(100 \mathrm{MHz}): \delta 132.99\left(\mathrm{C}_{\text {thio }}\right)$, $132.13\left(\mathrm{C}_{\text {arom }}\right), 131.90\left(\mathrm{C}_{\text {arom }}\right), 127.31\left(\mathrm{C}_{\text {arom }}\right), 124.63\left(\mathrm{C}_{\text {thio }}\right)$, $118.33(\mathrm{C} \equiv \mathrm{N}), 112.03\left(\mathrm{C}_{\text {arom }}\right), 92.89(\mathrm{C} \equiv \mathrm{C}), 86.24(\mathrm{C} \equiv \mathrm{C})$. MS (EI): $m / z$ 334. Anal. calc. for $\mathrm{C}_{22} \mathrm{H}_{10} \mathrm{~N}_{2} \mathrm{~S}$ : C, 79.02; $\mathrm{H}$, 3.01; N, 8.38. Found: C, 78.77; H, 2.98; N, 8.16\%.

2,5-Bis(para-carbomethoxyphenylethynyl)thiophene (1h). The compounds 2,5-diiodothiophene $(0.67 \mathrm{~g}, 2.00 \mathrm{mmol})$, $\mathrm{Pd}\left(\mathrm{PPh}_{3}\right)_{2} \mathrm{Cl}_{2}(0.03 \mathrm{~g}, 0.04 \mathrm{mmol})$ and $\mathrm{CuI}(0.008 \mathrm{~g}, 0.04$ $\mathrm{mmol})$ were added under nitrogen to a Schlenk flask. Dry, de-gassed $\mathrm{NEt}_{3}(50 \mathrm{~mL})$ was added via a cannula and 4carbomethoxyphenylacetylene $(0.67 \mathrm{~g}, 4.20 \mathrm{mmol})$ was then 
Table 3 Crystal data ${ }^{a}$

\begin{tabular}{|c|c|c|c|c|}
\hline Compound & 1a & $1 b$ & 1h & 2 \\
\hline CCDC no. & 641166 & 641167 & 641168 & 641169 \\
\hline Formula & $\mathrm{C}_{20} \mathrm{H}_{12} \mathrm{~S}$ & $\mathrm{C}_{22} \mathrm{H}_{16} \mathrm{~S}$ & $\mathrm{C}_{24} \mathrm{H}_{16} \mathrm{O}_{4} \mathrm{~S}$ & $\mathrm{C}_{20} \mathrm{H}_{2} \mathrm{~F}_{10} \mathrm{~S}$ \\
\hline Formula weight & 284.38 & 312.41 & 400.43 & 464.28 \\
\hline$T / \mathrm{K}$ & 120 & 120 & 120 & 120 \\
\hline Symmetry & Monoclinic & Monoclinic & Orthorhombic & Monoclinic \\
\hline Space group (no.) & $P 2_{1} / n(\# 14)$ & $P 2_{1} / n(\# 14)$ & Pca2 $_{1}(\# 29)$ & $P 2_{1} / n(\# 14)$ \\
\hline a/Å & 14.752(1) & $16.072(2)$ & $7.1798(8)$ & $4.9212(7)$ \\
\hline$b / \AA$ & $5.7461(2)$ & $5.0902(5)$ & $45.453(4)$ & $31.274(4)$ \\
\hline$c / \AA$ & 17.339(1) & $21.234(2)$ & $5.8879(4)$ & $11.3413(15)$ \\
\hline$\beta /^{\circ}$ & $90.87(1)$ & $112.22(1)$ & 90 & $101.83(1)$ \\
\hline$V / \AA^{3}$ & $1469.6(1)$ & $1608.1(3)$ & $1921.5(3)$ & $1708.4(4)$ \\
\hline$Z$ & 4 & 4 & 4 & 4 \\
\hline$\mu / \mathrm{mm}^{-1}$ & 0.21 & 0.20 & 0.20 & 0.30 \\
\hline Reflections collected & 9135 & 17948 & 19478 & 16756 \\
\hline Unique reflections & $3365,2098^{b}$ & $4255,3243^{b}$ & $4881,4505^{b}$ & $3921,3129^{b}$ \\
\hline$R_{\text {int }}$ & 0.067 & 0.048 & 0.033 & 0.039 \\
\hline$R(F)^{b}$ & 0.050 & 0.046 & 0.046 & 0.047 \\
\hline$w R\left(F^{2}\right)$ & 0.127 & 0.109 & 0.116 & 0.110 \\
\hline
\end{tabular}

added under a positive pressure of nitrogen. The reaction mixture was stirred at room temperature for $66 \mathrm{~h}$ and then heated at $80{ }^{\circ} \mathrm{C}$ for $2 \mathrm{~h}$. The $\mathrm{NEt}_{3}$ was then removed in vacuo. The residual solid was added to the top of a $5 \mathrm{~cm}$ silica gel column eluted with $1: 1 \mathrm{CH}_{2} \mathrm{Cl}_{2} /$ hexane and the solvents were removed in vacuo. Analytically pure product was isolated as a pale yellow solid after recrystallisation from hot toluene/ hexane solution. Yield: $0.40 \mathrm{~g}(50 \%)$, m.p. $201.5-202.5^{\circ} \mathrm{C}$. IR (/cm $\left.{ }^{-1}\right) 1602$ (arene ring), $1717(\mathrm{C}=\mathrm{O}$, asym), 2191 $\left(\mathrm{C} \equiv \mathrm{C}\right.$, asym). Raman (/ $\left.\mathrm{cm}^{-1}\right)$ 1448, 1607 (arene ring), 1717 (C=O, sym), 2197 (C $\equiv \mathrm{C}$, sym). ${ }^{1} \mathrm{H}$ NMR (200 MHz): $\delta 8.03$ (d, $\left.J=8 \mathrm{~Hz}, 4 \mathrm{H}, \mathrm{CH}_{\text {arom }}\right), 7.58\left(\mathrm{~d}, J=8 \mathrm{~Hz}, 4 \mathrm{H}, \mathrm{CH}_{\text {arom }}\right)$, 7.21 (s, $\left.2 \mathrm{H}, \mathrm{CH}_{\text {thiophene }}\right), 3.94\left(\mathrm{~s}, 6 \mathrm{H}, \mathrm{CO}_{2} \mathrm{Me}\right) .{ }^{13} \mathrm{C}\left\{{ }^{1} \mathrm{H}\right\}$ NMR (100 MHz): $\delta 166.42\left(\mathrm{CO}_{2}\right), 132.54\left(\mathrm{C}_{\text {thio }}\right), 131.35$ $\left(\mathrm{C}_{\text {arom }}\right), 129.91 \quad\left(\mathrm{C}_{\text {arom }}\right), 129.59\left(\mathrm{C}_{\text {arom }}\right), 127.16\left(\mathrm{C}_{\text {arom }}\right)$, $124.73\left(\mathrm{C}_{\text {thio }}\right), 93.66(\mathrm{C} \equiv \mathrm{C}), 85.02(\mathrm{C} \equiv \mathrm{C}), 52.26\left(\mathrm{CH}_{3}\right)$. MS (EI): $m / z$ 401. Anal. calc. for $\mathrm{C}_{24} \mathrm{H}_{16} \mathrm{O}_{4} \mathrm{~S}: \mathrm{C}, 71.98 ; \mathrm{H}$, 4.03. Found: C, 71.77; H, 3.96\%.

2,5-Bis(pentafluorophenylethynyl)thiophene (2). The compounds 2,5-diiodothiophene $(0.67 \mathrm{~g}, \quad 2.00 \mathrm{mmol})$, $\mathrm{Pd}\left(\mathrm{PPh}_{3}\right)_{2} \mathrm{Cl}_{2}(0.03 \mathrm{~g}, 0.04 \mathrm{mmol})$ and $\mathrm{CuI}(0.008 \mathrm{~g}, 0.04$ mmol) were added under nitrogen to a Schlenk flask. Dry, de-gassed $\mathrm{NEt}_{3}(50 \mathrm{~mL})$ was added via a cannula and pentafluorophenylacetylene $(0.81 \mathrm{~g}, 4.20 \mathrm{mmol})$ was then added under a positive pressure of nitrogen. The reaction mixture was stirred at room temperature for $24 \mathrm{~h}$ and the $\mathrm{NEt}_{3}$ was then removed in vacuo. The residual solid was added to the top of a $5 \mathrm{~cm}$ silica gel column eluted with $1: 1 \mathrm{CH}_{2} \mathrm{Cl}_{2} /$ hexane and the solvents were removed in vacuo. The product was recrystallised from a hot hexane/toluene solution to give the analytically pure material as large yellow crystals. Yield $0.39 \mathrm{~g}$, (42\%), m.p. $153.7-156.1{ }^{\circ} \mathrm{C}$. IR $\left(/ \mathrm{cm}^{-1}\right) 1532$ (arene ring), $2218\left(\mathrm{C} \equiv \mathrm{C}\right.$, asym). Raman $\left(/ \mathrm{cm}^{-1}\right) 1424$ (arene ring), 2217 (C $\equiv \mathrm{C}$, sym). ${ }^{1} \mathrm{H}$ NMR (200 MHz): $\delta 7.32$ (s, $2 \mathrm{H}$, $\left.\mathrm{CH}_{\text {thiophene }}\right) .{ }^{19} \mathrm{~F}\left\{{ }^{1} \mathrm{H}\right\}$ NMR (188 MHz): $\delta-135.70(\mathrm{~m}, 4 \mathrm{~F}$, $\left.\mathrm{CF}_{\text {arom }}\right),-151.64\left(\mathrm{t},{ }^{3} J_{\mathrm{FF}}=21 \mathrm{~Hz}, 2 \mathrm{~F}, \mathrm{CF}_{\text {arom }}\right),-161.66$ (m, $\left.4 \mathrm{~F}, \mathrm{CF}_{\text {arom }}\right) .{ }^{13} \mathrm{C}\left\{{ }^{1} \mathrm{H}\right\} \operatorname{NMR}(126 \mathrm{MHz}): \delta 147.21$ $\left(\mathrm{d}, J_{\mathrm{CF}}=242 \mathrm{~Hz}, \mathrm{C}_{\text {arom }}\right), 142.08\left(\mathrm{~d}, J_{\mathrm{CF}}=258 \mathrm{~Hz}, \mathrm{C}_{\text {arom }}\right)$, $140.90\left(\mathrm{~d}, J_{\mathrm{CF}}=252 \mathrm{~Hz}, \mathrm{C}_{\text {arom }}\right), 133.85\left(\mathrm{C}_{\text {thio }}\right), 124.51\left(\mathrm{C}_{\text {thio }}\right)$, 99.87 (t, $\left.J=13 \mathrm{~Hz}, \mathrm{C}_{\text {arom }}\right), 93.67$ (C $\left.\equiv \mathrm{C}\right), 78.70(\mathrm{C} \equiv \mathrm{C})$. MS (EI): $m / z$ 464. Anal. calc. for $\mathrm{C}_{20} \mathrm{H}_{2} \mathrm{~F}_{10} \mathrm{~S}$ : C, 51.74; H, 0.43 . Found: C, 51.55; H, 0.48\%.

\section{X-Ray crystallography}

Single-crystal diffraction experiments (Table 3) were carried out on Bruker three-circle diffractometers with CCD area detectors SMART $1 \mathrm{~K}$ or, for $\mathbf{1 h}$, SMART $6 \mathrm{~K}$, using graphite-monochromated Mo- $\mathrm{K}_{\alpha}$ radiation $(\lambda=0.71073 \AA)$ and Cryostream (Oxford Cryosystems) open-flow $\mathrm{N}_{2}$ cryostats. The structures were solved by direct methods and refined by full-matrix least-squares against $F^{2}$ on all data using SHELXTL software. ${ }^{54}$ Non-hydrogen atoms were refined in anisotropic and hydrogen atoms in isotropic approximations.

\section{Acknowledgements}

T. B. M., A. B. and J. A. K. H. thank One NorthEast for support through the Nanotechnology UIC programme. T. B. M. and J.-F. H. thank the Royal Society and the CNRS for their support of this collaboration via an International Joint Project-Europe Grant. R. M. W., A. L. T., S. R. R. and L. A. thank the EPSRC for postgraduate studentships. We thank Ms K. Wongkhan for a preliminary optical polarised light microscopy examination of compound $\mathbf{1 g}$. We are grateful to Durham University for the provision of high-performance computer facilities.

\section{References}

1 P. Nguyen, Z. Yuan, L. Agocs, G. Lesley and T. B. Marder, Inorg. Chim. Acta, 1994, 220, 289.

2 M. S. Khan, A. K. Kakkar, N. J. Long, J. Lewis, P. Raithby, P. Nguyen, T. B. Marder, F. Whittmann and R. H. Friend, J. Mater. Chem., 1994, 4, 1227.

3 (a) P. Nguyen, G. Lesley, T. B. Marder, I. Ledoux and J. Zyss, Chem. Mater., 1997, 9, 406; (b) M. Biswas, P. Nguyen, T. B. Marder and L. R. Khundkar, J. Phys. Chem. A, 1997, 101, 1689. 
4 (a) C. Dai, P. Nguyen, T. B. Marder, A. J. Scott, W. Clegg and C. Viney, Chem. Commun., 1999, 2493; (b) S. W. Watt, C. Dai, A. J. Scott, J. M. Burke, R. Ll. Thomas, J. C. Collings, C. Viney, W. Clegg and T. B. Marder, Angew. Chem., Int. Ed., 2004, 43, 3061. 5 U. H. F. Bunz, Chem. Rev., 2000, 100, 1605.

6 Z. L. Donhauser, B. A. Mantooth, K. F. Kelly, L. A. Bumm, J. D. Monnell, J. J. Stapleton, D. W. Price, A. M. Rawlett, D. L. Allara, J. M. Tour and P. S. Weiss, Science, 2001, 292, 2303.

7 S. M. Dirk, D. W. Price, S. Chanteau, D. V. Kosynkin and J. M. Tour, Tetrahedron, 2001, 57, 5109.

8 J. Kim and T. M. Swager, Nature, 2001, 411, 1030.

9 C. Schmitz, P. Posch, M. Thelakkat, H. W. Schmidt, A. Montak, K. Feldman, P. Smith and C. Weder, Adv. Funct. Mater., 2001, 11, 41.

10 S. Lahiri, J. L. Thompson and J. S. Moore, J. Am. Chem. Soc., 2000, 122, 11315 .

11 M. Levitus, K. Schmieder, H. Ricks, K. D. Shimizu, U. H. F. Bunz and M. A. Garcia-Garibay, J. Am. Chem. Soc., 2001, 123, 4259.

12 H. Li, D. R. Powell, T. K. Firman and R. West, Macromolecules, 1998, 31, 1093.

13 (a) For an experimental study on the rotation barriers of the aryl rings in BPEBs, see: S. J. Greaves, E. L. Flynn, E. L. Futcher, E. Wrede, D. P. Lydon, P. J. Low, S. R. Rutter and A. Beeby, J. Phys. Chem. A, 2006, 110, 2114; (b) For a modelling study on the effects of torsional disorder on the spectra of poly- and oligo-paraphenyleneethynylenes, see: L. T. Liu, D. Yaron, M. I. Sluch and M. A. Berg, J. Phys. Chem. B, 2006, 110, 18844.

14 (a) T. M. Fasina, J. C. Collings, J. M. Burke, A. S. Batsanov, R. M. Ward, D. Albesa-Jové, L. Porrès, A. Beeby, J. A. K. Howard, A. J. Scott, W. Clegg, S. W. Watt, C. Viney and T. B. Marder, J. Mater. Chem., 2005, 15, 690; (b) T. M. Fasina, J. C. Collings, D. P. Lydon, D. Albesa-Jové, A. S. Batsanov, J. A. K. Howard, P. Nguyen, M. Bruce, A. J. Scott, W. Clegg, S. W. Watt, C. Viney and T. B. Marder, J. Mater. Chem., 2004, 14, 2395.

15 (a) A. Beeby, K. S. Findlay, P. J. Low, T. B. Marder, P. Matousek, A. W. Parker, S. R. Rutter and M. Towrie, Chem. Commun., 2003, 2406; (b) A. Beeby, K. S. Findlay, P. J. Low and T. B. Marder, J. Am. Chem. Soc., 2001, 124, 8280; (c) D. P. Lydon, L. Porrès, A. Beeby, T. B. Marder and P. J. Low, New J. Chem., 2005, 29, 972; (d) J. M. Tour, Chem. Rev., 1996, 96, 537; (e) R. Giesa, J. Macromol. Sci., Rev. Macromol. Chem. Phys., 1996, C36, 631.

16 (a) P. Nguyen, S. Todd, D. van den Biggelaar, N. J. Taylor, T. B. Marder, F. Wittmann and R. H. Friend, Synlett, 1994, 299; (b) P. Nguyen, G. Lesley, C. Dai, N. J. Taylor, T. B. Marder, V. Chu, C. Viney, I. Ledoux and J. Zyss, in NATO ASI Series E: Applications of Organometallic Chemistry in the Preparation and Processing of Advanced Materials, ed. J. F. Harrod and R. M. Laine, Kluwer Academic, Dordrecht, 1995, vol. 297, pp. 333-347; (c) P. Nguyen, S. Todd, D. van den Biggelaar, N. J. Taylor, J. C. Collings, R. M. Ward, R. Ll. Thomas, D. P. Lydon, L. Porrès, S. R. Rutter, K. S. Findlay, A. Beeby, O. F. Koentjoro, P. J. Low, A. S. Batsanov, D. S. Yufit, A. L. Thompson, J. A. K. Howard, A. J. Scott, W. Clegg, S. W. Watt, C. Viney and T. B. Marder, in preparation.

17 T. Kawai, T. Saski and M. Irie, Chem. Commun., 2001, 711.

18 S. Nakatesuji, K. Matsuda, Y. Uesugi, K. Nakashima, S. Akiyama and W. Fabian, J. Chem. Soc., Perkin Trans. 1, 1992, 7, 755.

19 J. G. Rodríguez, A. Lafuente, L. Rubio and J. Esquivias, Tetrahedron Lett., 2004, 45, 7061.

20 J. G. Rodríguez, J. Esquivias, A. Lafuente and L. Rubio, Tetrahedron Lett., 2006, 62, 3112.

21 S.-S. Sun and A. J. Lees, J. Am. Chem. Soc., 2000, 122, 8956.

22 T. S. Jung, J. H. Kim, E. K. Jang, D. H. Kim, Y.-B. Shim, B. Park and S. C. Shin, J. Organomet. Chem., 2000, 599, 232.

23 A. J. Boydston, Y. Yin and B. L. Pagenkopf, J. Am. Chem. Soc., 2004, 126, 3724.

24 T. Yasuda, T. Imase, Y. Nakamura and T. Yamamoto, Macromolecules, 2005, 38, 4687.

25 P. Lind, C. Lopes, K. Öberg and B. Eliasson, Chem. Phys. Lett., 2004, 387, 238.

26 P. Lind, A. Eriksson, C. Lopes and B. Eliasson, J. Phys. Org. Chem., 2005, 18, 426.

27 R. Vestberg, C. Nilsson, C. Lopes, P. Lind, B. Eliasson and E. Malmstrom, J. Polym. Sci., Part A: Polym. Chem., 2005, 43, 1177.

28 S. H. Eichhorn, A. J. Paraskos, K. Kishikawa and T. M. Swager, J. Am. Chem. Soc., 2002, 124, 12742.
29 G. Heppke and D. Moro, Science, 1998, 279, 1872.

30 (a) H.-F. Hsu, C.-H. Kuo, C.-F. Chen, Y.-H. Lin, L.-Y. Huang, C.-H. Chen, K.-C. Cheng and H.-H. Chen, Chem. Mater., 2004, 16, 2379; (b) J. Han, Y.-M. Wang and X.-G. Wang, Chin. J. Chem., 2006, 24, 1594.

31 K. Kishikawa, M. C. Harris and T. M. Swager, Chem. Mater., 1999, 11, 867

32 S. Löhr, M. Yonemura, A. Orita, N. Imai, H. Akashi and J. Otera, Acta Crystallogr., Sect. E: Struct. Rep. Online, 2003, 59, 594.

33 (a) S. Schouteeten, J.-P. Tranchier, F. Rose-Munch, E. Rose, A. Auffrant and G. R. Stephenson, Organometallics, 2004, 23, 4308; (b) W. L. Dreissen and T. X. Neenan, Acta Crystallogr., Sect. C: Cryst. Struct. Commun., 1996, 52, 59; (c) S. U. Son, B. Y. Kim, C. H. Choi, S. W. Lee, Y. S. Kim and Y. K. Chung, Chem. Commun., 2003, 2528; (d) A. N. Sokolov, T. Friščič and L. R. MacGillivray, J. Am. Chem. Soc., 2006, 128, 2806.

34 K. Sanechika, T. Yamamoto and A. Yamamoto, Bull. Chem. Soc. Jpn., 1984, 57, 752 .

35 M. A. Penz, I. Perez, J. P. Sestelo and L. A. Sarandeses, Chem. Commun., 2002, 2246.

36 A. Orita, F. Ye, G. Babu, T. Ikemoto and J. Otera, Can. J. Chem., $2005,83,716$.

37 F. Freeman and D. S. H. Kim, J. Org. Chem., 1992, 57, 1722.

38 (a) J. P. Rourke, A. S. Batsanov, J. A. K. Howard and T. B. Marder, Chem. Commun., 2001, 2626; (b) Detailed studies of the synthesis, structure and photophysical properties of the rhodacyclopentadienes will be reported elsewhere.

39 A. Beeby, H. E. Burrows, I. Clark, K. S. Findlay, P. Matousek, A. W. Parker, R. E. Pierce, L. Porrès, S. R. Rutter and M. Towrie, in preparation.

40 K. Sonogashira, Y. Tohda and N. Hagihara, Tetrahedron Lett., $1975,4467$.

41 A. Köhler, J. S. Wilson, R. H. Friend, M. K. Al-Suti, M. S. Khan, A. Gerhard and H. Bässler, J. Chem. Phys., 2002, 116, 9457.

42 A. S. Batsanov, J. C. Collings, I. J. S. Fairlamb, J. P. Holland, J. A. K. Howard, Z. Y. Lin, T. B. Marder, A. C. Parsons, R. M. Ward and J. Zhu, J. Org. Chem., 2005, 70, 703.

43 C. Hansch, A. Leo and R. W. Taft, Chem. Rev., 1991, 91, 165.

44 F. Dunstetter, D. André, A. Gonthier-Vassal, H. Szwarc, N. Ratovelomanana and M.-F. Lautie, Chem. Phys., 1993, 175, 475.

45 I. V. Kochikov, Yu. I. Tarasov, V. P. Spiridonov, G. M. Kuramshina, D. W. H. Rankin, A. S. Saakjan and A. G. Yagola, J. Mol. Struct., 2001, 567-568, 29.

46 (a) A. V. Abramenkov, A. Almenningen, B. N. Cyvin, S. J. Cyvin, T. Tonvik, L. S. Khaikin, C. Romming and L. V. Vilkov, Acta Chem. Scand. Ser. A, 1988, 42, 674; (b) I. E. Zanin, M. Yu. Antipin and Yu. T. Struchkov, Kristallografiya, 1991, 36, 411.

47 M. J. Frisch, G. W. Trucks, H. B. Schlegel, G. E. Scuseria, M. A. Robb, J. R. Cheeseman, J. A. Montgomery, Jr, T. Vreven, K. N. Kudin, J. C. Burant, J. M. Millam, S. S. Iyengar, J. Tomasi, V. Barone, B. Mennucci, M. Cossi, G. Scalmani, N. Rega, G. A. Petersson, H. Nakatsuji, M. Hada, M. Ehara, K. Toyota, R. Fukuda, J. Hasegawa, M. Ishida, T. Nakajima, Y. Honda, O. Kitao, H. Nakai, M. Klene, X. Li, J. E. Knox, H. P. Hratchian, J. B. Cross, V. Bakken, C. Adamo, J. Jaramillo, R. Gomperts, R. E. Stratmann, O. Yazyev, A. J. Austin, R. Cammi, C. Pomelli, J. W. Ochterski, P. Y. Ayala, K. Morokuma, G. A. Voth, P. Salvador, J. J. Dannenberg, V. G. Zakrzewski, S. Dapprich, A. D. Daniels, M. C. Strain, O. Farkas, D. K. Malick, A. D. Rabuck, K. Raghavachari, J. B. Foresman, J. V. Ortiz, Q. Cui, A. G. Baboul, S. Clifford, J. Cioslowski, B. B. Stefanov, G. Liu, A. Liashenko, P. Piskorz, I. Komaromi, R. L. Martin, D. J. Fox, T. Keith, M. A. Al-Laham, C. Y. Peng, A. Nanayakkara, M. Challacombe, P. M. W. Gill, B. Johnson, W. Chen, M. W. Wong, C. Gonzalez and J. A. Pople, GAUSSIAN 03 (Revision B.05), Gaussian, Inc., Wallingford CT, 2004.

48 A. P. Scott and L. Radom, J. Phys. Chem., 1996, 100, 16502.

49 (a) M. Tsuji, J. Org. Chem., 2003, 68, 9589; (b) P. R. Serwinski and P. M. Lahti, Org. Lett., 2003, 5, 2099; (c) D. L. Musso, M. J. Clarke, J. L. Kelley, G. E. Boswell and G. Chen, Org. Biomol. Chem., 2003, 1, 498; (d) Y. Miki, A. Momotake and T. Arai, Org. Biomol. Chem., 2003, 1, 2655; (e) W. B. Austin, N. Bilow, W. J. Kelleghan and K. S. Y. Lau, J. Org. Chem., 1981, 46, 2280; (f) Y. Zhang and J. Wen, Synthesis, 1990, 727; $(g)$ C. Dai, Z. Yuan, 
J. C. Collings, T. M. Fasina, R. L. Thomas, K. P. Roscoe, L. M. Stimpson, D. S. Yufit, A. S. Batsanov, J. A. K. Howard and T. B. Marder, CrystEngComm, 2004, 6, 184; $(h)$ A. S. Batsanov, J. C. Collings, R. M. Ward, A. E. Goeta, L. Porres, A. Beeby, J. A. K. Howard, J. W. Steed and T. B. Marder, CrystEngComm, 2006, 8, 622.

50 J. R. Lakowicz, Principles of Fluorescence Spectroscopy, Kluwer, New York, 2nd edn, 1999.
51 A. Pardo, D. Reyman, J. M. L. Poyato and F. Medina, J. Lumin., 1992, 51, 269.

52 D. V. O'Connor and D. Phillips, Time Correlated Single Photon Counting, Academic Press, London, 1984.

53 D. V. O'Connor, W. R. Ware and J. C. Andre, J. Phys. Chem., 1979, 83, 1333.

54 G. M. Sheldrick, SHELXTL version 6.14, Bruker-Nonius, AXS, Madison, Wisconsin, USA, 2003. 